\title{
Is the meiofauna a good indicator for climate change and anthropogenic impacts?
}

\author{
Daniela Zeppilli ${ }^{1,10}$ - Jozée Sarrazin ${ }^{1}$ - Daniel Leduc ${ }^{2}$ Pedro Martinez Arbizu ${ }^{3}$. \\ Diego Fontaneto ${ }^{4}$. Christophe Fontanier ${ }^{5}$ Andrew J. Gooday ${ }^{6}$. \\ Reinhardt Møbjerg Kristensen ${ }^{7}$ - Viatcheslav N. Ivanenko ${ }^{8} \cdot$ Martin V. Sørensen $^{7}$. \\ Ann Vanreusel ${ }^{9}$. Julien Thébault ${ }^{10}$ - Marianna Mea ${ }^{11}$. Noémie Allio ${ }^{10}$. \\ Thomas Andro $^{10}$ - Alexandre Arvigo ${ }^{10}$. Justine Castrec ${ }^{10} \cdot$ Morgan Danielo $^{10}$. $^{\circ}$ \\ Valentin Foulon $^{10}$ - Raphaelle Fumeron ${ }^{10}$ - Ludovic Hermabessiere ${ }^{10}$ - Vivien Hulot ${ }^{10}$. $^{10}$ \\ Tristan James $^{10}$ • Roxanne Langonne-Augen ${ }^{10}$ • Tangi Le Bot ${ }^{10}$ • Marc Long ${ }^{10}$. \\ Dendy Mahabror $^{10}$ • Quentin Morel ${ }^{10}$ - Michael Pantalos ${ }^{10}$. Etienne Pouplard ${ }^{10}$. \\ Laura Raimondeau ${ }^{10}$ - Antoine Rio-Cabello ${ }^{10}$ - Sarah Seite $^{10} \cdot$ Gwendoline Traisnel $^{10}$. \\ Kevin Urvoy $^{10}$ • Thomas Van Der Stegen ${ }^{10} \cdot$ Mariam Weyand $^{10} \cdot$ David Fernandes $^{12}$
}

Received: 21 October 2014 / Revised: 1 June 2015 / Accepted: 16 June 2015 /Published online: 5 July 2015

(C) The Author(s) 2015. This article is published with open access at Springerlink.com

\begin{abstract}
Our planet is changing, and one of the most pressing challenges facing the scientific community revolves around understanding how ecological communities respond to global changes. From coastal to deep-sea ecosystems, ecologists are exploring new areas of research to find model organisms that help predict the future of life on our planet. Among the different categories of organisms, meiofauna offer several advantages for the study of marine benthic ecosystems. This paper reviews the advances in the study of meiofauna with regard to climate change and anthropogenic impacts. Four taxonomic groups are valuable for predicting
\end{abstract}

Communicated by S. S. M. Kaiser

Daniela Zeppilli

Daniela.Zeppilli@ifremer.fr

1 IFREMER, Centre Brest, REM/EEP/LEP, Institut Carnot Ifremer-EDROME, ZI de la pointe du diable, CS10070, 29280 Plouzané, France

2 National Institute of Water and Atmospheric Research, Private Bag 14-901, Wellington 6021, New Zealand

3 Senckenberg am Meer, DZMB, Wilhelmshaven, Germany

4 National Research Council, Institute of Ecosystem Study, Largo Tonolli 50, 28922 Verbania Pallanza, Italy

5 IFREMER, Centre Brest, REM/GM/LES, Institut Carnot Ifremer-EDROME, ZI de la pointe du diable, CS10070, 29280 Plouzané, France global changes: foraminifers (especially calcareous forms), nematodes, copepods and ostracods. Environmental variables are fundamental in the interpretation of meiofaunal patterns and multistressor experiments are more informative than single stressor ones, revealing complex ecological and biological interactions. Global change has a general negative effect on meiofauna, with important consequences on benthic food webs. However, some meiofaunal species can be favoured by the extreme conditions induced by global change, as they can exhibit remarkable physiological adaptations. This review highlights the need to incorporate studies on taxonomy,
6 National Oceanography Centre, University of Southampton Waterfrount Campus, European Way, Southampton S014 3ZH, UK

7 Natural History Museum of Denmark, University of Copenhagen, Universitetsparken 15, 2100 Copenhagen Ø, Denmark

8 Department of Invertebrate Zoology, Biological Faculty, Lomonosov Moscow State University, Moscow, Russia

9 Department of Biology, Marine Biology Section, Ghent University, Krijgslaan 281, S8, 9000 Ghent, Belgium

10 Université de Brest, Institut Universitaire Européen de la Mer, Laboratoire des sciences de l'environnement marin (UMR6539 CNRS/IRD/UBO), rue Dumont d'Urville, 29280 Plouzané, France

11 SEAMap srl, Via Ponti 11, 17052, Borghetto Santo Spirito, 17052 Savona, Italy

12 IFREMER, Centre Brest, BLP, Institut Carnot Ifremer-EDROME, ZI de la pointe du diable, CS10070, 29280 Plouzané, France 
genetics and function of meiofaunal taxa into global change impact research.

Keywords Meiofauna $\cdot$ Climate change $\cdot$ Anthropogenic impacts $\cdot$ Biomonitoring $\cdot$ Natural observations and experimental studies

\section{Introduction}

The role of humans in altering the environment at a global scale is becoming increasingly evident (IPCC 2014); thus, it is crucial to understand the consequences of changes for life on Earth and human societies (Rudd 2014). In particular, the consequences of human actions on the environment need to be understood to mitigate their impacts. Since the effects will occur at a broad scale, understanding and attenuating potential global changes represents a tremendous scientific challenge.

The major global change that we are experiencing is linked to climate. Climate can be defined as the average weather in terms of the mean and its variability over a certain time span (Baede et al. 2001), while climate change can be defined as any systematic change in the climate system that is sustained over several decades or longer (Sijp et al. 2014). In the present study, we consider mainly the current climate change. Global surface warming has taken place at a rate of $0.74 \pm 0.18{ }^{\circ} \mathrm{C}$ over the last 100 years (1906-2005) and the warming rate over the last 50 years is almost twice that of the entire 100-year period (IPCC 2007). Global warming itself expresses only one aspect of climate change. Global sea level rising, melting of ice sheets, and extreme weather events are other important aspects of climate change (Freedman 2014). Modelling studies predict that climate change over the next century will have profound consequences for marine biota, as well as for human populations living in coastal regions (Jones et al. 2013; Mora et al. 2013). With a constantly growing population and high energetic demands, human activities significantly affect ecosystems (Bampton 1999), and anthropogenic impacts are driving the observed changes (Barron 1989). Determining the ecological impact of humans on marine ecosystems requires a deep understanding of their interactions with these ecosystems (Kennedy and Jacoby 1999).

When compared with other ecosystem compartments included in models that aim at predicting and understanding global changes, meiofauna offer several advantages. Meiofauna is a collective name for one of the most diversified communities of the marine realm, including small organisms, unicellular protists and multicellular metazoans that live in aquatic sediments (Giere 2009; Fig. 1). Due to their high abundance and diversity, their widespread distribution, their rapid generation time and fast metabolic rates, meiofaunal organisms are vital contributors to ecosystem function, including nutrient cycling and the provision of energy to higher trophic levels (Woodward 2010). These characteristics make meiofaunal organisms excellent candidates to test general ecological hypotheses and theories (Jessup et al. 2004; Nascimento et al. 2011, 2012; Bonaglia et al. 2014). However, this group represents an often neglected component of marine biodiversity (Curini-Galletti et al. 2012) and is generally poorly studied (particularly in the deep sea) because most applied programmes target the larger macrofauna, which are more readily identifiable and countable than meiofauna (Schratzberger et al. 2000).

To assess the general potential of meiofauna for predicting and assessing global change and other anthropogenic stressors, here we review advances in the study of meiofauna with regard to climate change and human impacts, preceded by a background session about the importance of meiofauna in marine benthic ecosystems. We conclude by suggesting perspectives and limits for the use of meiofauna as model organisms in future research related to global change.

\section{Background}

The term meiofauna (from the Greek $\mu$ cícuv smaller) was coined in 1942 by Molly F. Mare "to define an assemblage of benthic metazoans that can be distinguished from macrofauna by their small sizes." Considering the size boundaries (operationally defined based on the standardised mesh size of sieves with $1000 \mu \mathrm{m}$ and $20 \mu \mathrm{m}$ as upper and lower limits, respectively; Danovaro 2010), protists are also considered part of meiofauna (Giere 2009). Meiofauna represent the most diversified group in the marine realm, encompassing 24 of the 35 animal phyla, as well as one important group of protists, the foraminifera (Giere 2009). Meiofauna are mostly found in and on soft sediments, but also on and among epilithic plants and other types of substrata (e.g., animal tubes; Pinto et al. 2013). These small organisms can spend their complete life cycle without reaching sizes greater than $1 \mathrm{~mm}$ (permanent meiofauna), or be found in this size class for just a part of their life cycle (e.g., juveniles of macrofauna, referred to as temporary meiofauna; Hentschel and Jumars 1994). They are the most abundant size class in the benthos and are closely connected to other compartments of the benthos (including prokaryotes and macrofauna; Baldrighi et al. 2013). They play an important role in benthic food webs, not only as consumers (feeding on detritus, diatoms and algae, and preying on other small metazoans; Pergent et al. 1994; Duarte and Cebrian 1996; Gee and Somerfield 1997; Mateo and Romero 1997; Gwyther 2003; Torres-Pratts and Schizas 2007; Mascart et al. 2013, 2015), but also as producers (being a food source for macrofauna and fish; Gerlach 1978; Lebreton et al. 2011; Vinagre et al. 2012; Carpentier et al. 2014). The abundance, diversity, distribution and functional properties of meiofauna can be affected by several abiotic factors, including 

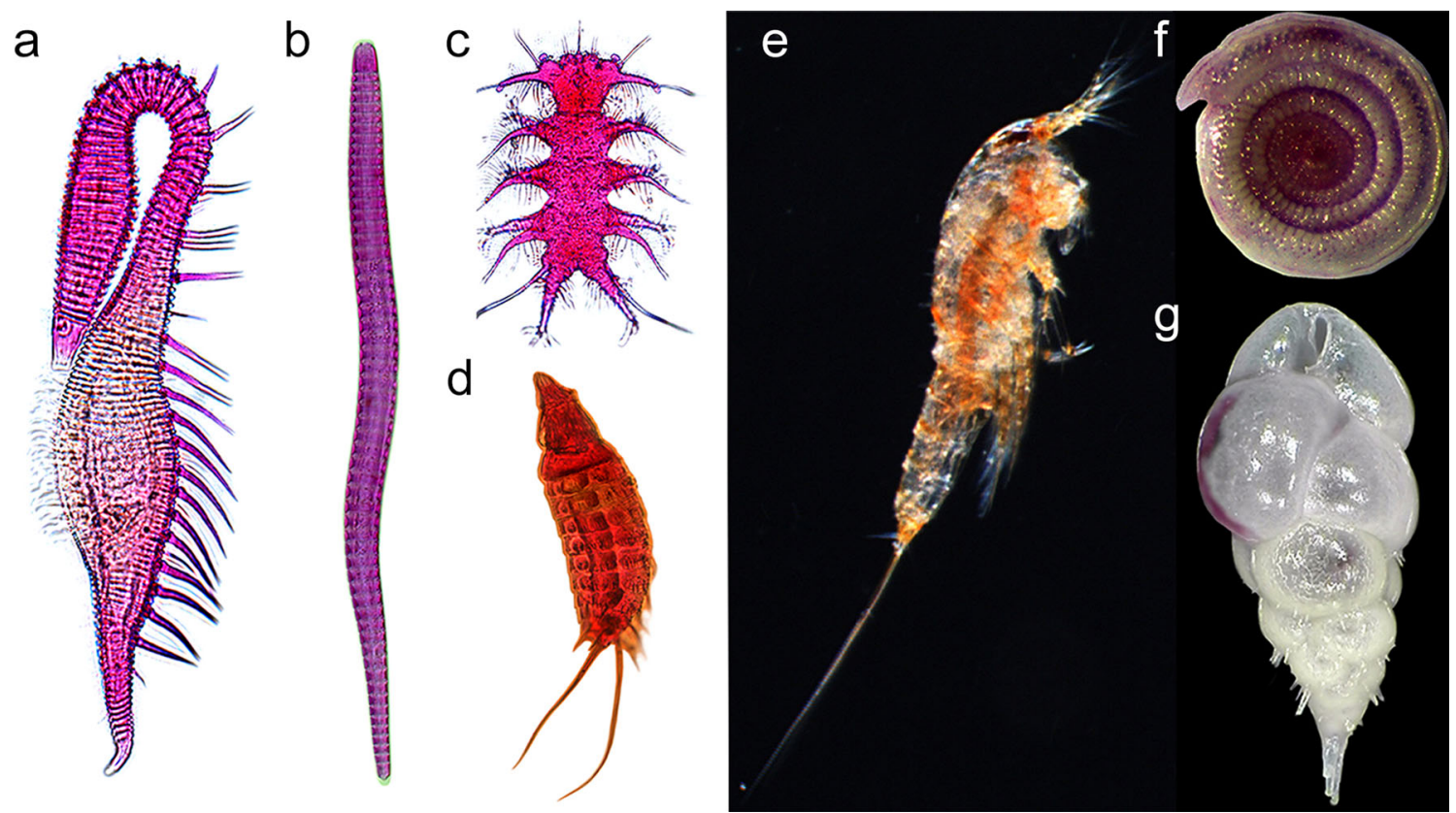

Fig. 1 Microscopic view of meiofauna. Representatives of selected meiofaunal taxa: a, b) Nematoda, c) Tardigrada, d) Kinorhyncha, e) Copepoda, f, g) Foraminifera. Credits: a, b, c, d: D. Zeppilli (IFREMER); e: Moorea Biocode project; f: C. Fontanier (IFREMER); g: Natural History Museum, London

temperature, salinity, hydrodynamic and sedimentary processes, sediment grain size, oxygenation level and food availability (Ingels et al. 2011; Lizhe et al. 2012; Ngo et al. 2013; Zeppilli et al. 2013; Górska et al. 2014; Pusceddu et al. 2014b), and also, by biotic factors such as predation and competition (Tita et al. 2000; Danovaro et al. 2007; Nascimento et al. 2011; Braeckman et al. 2013; Boldina et al. 2014). Meiofauna are characterised by a high sensitivity to environmental changes due to their short generation time and the lack of pelagic larval dispersion for the dominant meiofaunal groups (Bongers and Ferris 1999). Meiofauna can also modify their environments and promote the degradation of organic matter by stimulating microbial activity and bioturbating the sediment (Aller and Aller 1992; Giere 2009).

\section{Marine meiofaunal diversity and ecosystem functioning}

Ecosystem functions are considered as the sum of biological, geochemical, and physical processes that operate within an ecosystem, sustaining its overall performance and supplying ecosystem services (Edwards et al. 2014). Increased human pressure contributes to depauperate ecosystems, thereby potentially affecting their ability to provide essential services. The potential ecological consequences of biodiversity loss and the relationships between species diversity and ecosystem processes have aroused considerable interest in the scientific community (Loreau et al. 2001). It is now recognised that higher functional biodiversity contributes to a stable and resilient ecosystem (Tomimatsu et al. 2013). The marine environment covers a large majority ( $71 \%$ ) of the planet's surface, shows high levels of diversity at all scales, and is essential to global fluxes of materials, nutrients, and energy to other ecosystems (Hooper et al. 2005). Understanding the relationship between diversity and stability is one of the major challenges in marine ecosystems ecology (Borja 2014), and the highly diverse meiofauna were only recently included in ecosystem functioning research. Several studies have shown that meiofaunal species richness has a positive effect on ecosystem functions (Covich et al. 2004). However, shallow-water softsediment studies show that species identity and function seems to be more important than species richness for the maintenance of ecosystem functioning (Radwell and Brown 2008). For example, in an experimental study, De Mesel et al. (2006) provide evidence for an idiosyncratic relationship between nematode species diversity and function in low-diversity systems. Furthermore, limited functional overlap between nematode species is observed in low diversity systems (De Mesel et al. 2006; Gingold et al. 2013). Using deep-sea nematodes as model organisms, Danovaro et al. (2008) suggest that high nematode diversity may have a positive impact on deep-sea ecosystem functioning. This exponential diversity-function relationship may only apply to low diversity assemblages due to increased competition or greater functional redundancy in more diverse assemblages (Leduc et al. 2013). Although the positive relationship between diversity and ecosystem functioning is well defined when nematode species diversity is low in deep-sea ecosystems, the correlation is absent when species diversity is high (Leduc et al. 2013). This may explain why in the South Pacific, the relationship between diversity and ecosystem functioning appears weaker, whereas in other regions, 
such as the Atlantic Ocean and Mediterranean Sea, the relationship is stronger (Leduc et al. 2013). On the continental slope of the northwestern Mediterranean Sea, deep-sea fisheries have caused the collapse of benthic meiofaunal biodiversity and ecosystem functioning, with potential consequences on biogeochemical cycles (Pusceddu et al. 2014a). Moreover, a recent study assessed the influence of meiofauna on the relationship between macrofaunal biodiversity and ecosystem functioning (Piot et al. 2014), highlighting the fact that meiofauna may have a strong direct impact on benthic properties, by modifying the interactions between macrofaunal species, and therefore their impacts on ecosystem properties.

The ecological role of meiofauna in benthic ecosystems can be assessed by measuring the flow of energy. Small organisms are characterised by high dynamics (oxygen consumption and metabolism) and turnover (Gerlach 1971). Compared with macrofauna, meiofauna usually have low standing stock biomass, but high production (Giere 2009). In some shallow ecosystems, such as tidal flats, meiofaunal secondary production frequently exceeds that of macrofauna (Warwick et al. 1979; Kuipers et al. 1981). Small benthos, including meiofauna, clearly contribute substantially to production in sandy sublittoral ecosystems: up to $40 \%$ of the total benthic metabolism (Fenchel 1978). Generally, the biomass and organic matter cycling by small heterotrophs (meiofauna and bacteria) increase in importance with depth when resources are limited (Heip et al. 2001; Thistle 2001; Rowe et al. 2003; Baguley et al. 2005; Rex et al. 2006; Gontikaki et al. 2011). The depiction of meiofauna in energy flux diagrams suffers from a lack of ecological information for many constituent taxa (Giere 2009). The central role of detritus in the meiofaunal energy budget (Escaravage et al. 1989) derives from the consumption of detritus and microorganisms by the most abundant meiofaunal groups, nematodes and foraminifera (Gooday 2003; Murray 2006). Grazing meiofauna stimulate microbial activity by keeping the microbial population in its reproductive log-phase (Giere 2009). Many studies show that meiofauna feed on benthic microalgae, freshly sedimented phytodetritus and seagrass detritus (Lee 1980; Rudnick 1989; Riera et al. 1996; Olafsson and Elmgren 1997; Buffan-Dubau and Carman 2000; Gooday 2003; Murray 2006; Torres-Pratts and Schizas 2007; Mascart et al. 2013, 2015). Nematode responses to food availability as well as to other environmental factors can be species-specific with a complex relationship between species diversity and function (Dos Santos et al. 2008). Meiofauna represent, in turn, an important food resource for macrofauna and a variety of juvenile fish (Giere 2009). In situ and laboratory experiments give fairly accurate information on the role of foraminifera in the food web and energy transfer within benthic environments (e.g., Nomaki et al. 2005a, 2005b, 2006, 2009, 2010, 2011; Würzberg et al. 2011). Oxygen consumption rates in meiofaunal organisms are greater than in macrofaunal organisms (Mahaut et al. 1995). Meiofauna may be five times more metabolically active than macrofauna, consuming between 200 and $2000 \mathrm{~mm}^{3} \mathrm{O}_{2} / \mathrm{h} / \mathrm{g}$ wet weight compared to 200 to $500 \mathrm{~mm}^{3} \mathrm{O}_{2} / \mathrm{h} / \mathrm{g}$ wet weight for macrofauna in sublittoral sediments (Gerlach 1971). In the deep sea, the respiration rate of meiofauna increases with depth, whereas it decreases in larger organisms (Mahaut et al. 1995). For instance, deep-sea foraminifera (e.g., Uvigerina semiornata) from the IndoPakistan oxygen minimum zone (OMZ) dominate the uptake of fresh organic matter when bottom-water oxygenation is very low $(\sim 5 \mathrm{mmol} / \mathrm{L})$, whereas larger metazoans (polychaetes) are more efficient in food acquisition when oxygenation is higher (Woulds et al. 2007). Furthermore, benthic foraminifers are capable of denitrification as an alternative metabolic pathway (Risgaard-Petersen et al. 2006; PiñaOchoa et al. 2010a, b).

\section{Global climate change}

Climate change, caused by an increase in atmospheric carbon dioxide $\left(\mathrm{CO}_{2}\right)$ over the past centuries, has already caused significant shifts in marine and terrestrial ecosystems (Ingels et al. 2012). The direct consequences of increasing $\mathrm{CO}_{2}$ include the increase in ocean temperature (Bindoff et al. 2007) and acidity (Doney et al. 2009). The ocean temperature is warming (the upper $75 \mathrm{~m}$ of seawater has warmed by $0.11{ }^{\circ} \mathrm{C}$ per decade from 1971 to 2010 ), the sea level is rising (global mean sea level has risen by $0.19 \mathrm{~m}$ during the $1901-$ 2010 period) and sea surface salinity has increased by 0.13 PSS78 (Practical Salinity Scale 1978) from 1950 to 2008 (Durack and Wijffels 2010). $\mathrm{CO}_{2}$ concentrations in the atmosphere have increased up to $40 \%$ since pre-industrial times, primarily due to fossil fuel combustion and carbon emissions from land (IPCC 2014). Historically, the oceans absorbed approximately one-quarter of all $\mathrm{CO}_{2}$ released into the atmosphere, resulting in a $26 \%$ increase in the acidity of the ocean (IPCC 2014). Over the last four decades, the extent of hypoxic zones and OMZs has significantly increased (Diaz and Rosenberg 1995; Rabalais et al. 2010; Stramma et al. 2008 2010). Other changes may occur in ocean stratification and circulation (Doney et al. 2012). Climate change probably affects the number of hurricanes and causes changes in current systems, leading to the mass destruction of habitats. The speed of the current climate change is comparable with other dramatic episodes in our planet's history that led to mass extinction events (Van De Schootbrugge and Gollner 2013).

Modelling studies predict global changes in ocean temperature, $\mathrm{pH}$, oxygenation and primary production over the next century, with profound potential consequences for marine biota in general, as well as for human populations living in coastal regions (Jones et al. 2013; Mora et al. 2013). The effects of climate change are particularly evident in the Arctic 
Ocean and some parts of the Antarctic Ocean (Doney et al. 2012). In the latter, the low sea-surface temperature, leading to increased $\mathrm{CO}_{2}$ solubility and upwelling of rich $\mathrm{CO}_{2}$ deep water, has led to rapid acidification rates (Guinotte and Fabry 2008). In the Southern Hemisphere, the Antarctic Peninsula is experiencing one of the fastest rates of regional climate change on Earth (Turner et al. 2009) and Antarctic ecosystems are particularly vulnerable and sensitive to these changes (Ingels et al. 2012). Global climate warming also has secondary effects, such as large-scale ice-shelf disintegration events, changes in the availability, quantity and quality of food, and increased glacier melting leading to increased coastal turbidity and salinity modifications (Ingels et al. 2012). A summary of studies concerning the impact of climate change on marine meiofauna is reported in Tables 1 and 2 .

\section{Impact of global climate change on meiofauna}

\section{Response to ocean warming}

Recent studies have shown that meiofaunal communities respond to warming both in seawater and freshwater ecosystems (O’Gorman et al. 2012; Gingold et al. 2013). In freshwaters, macrofaunal and meio community composition has been shown to change dramatically across a thermal gradient, with indications of low food-web stability in warmer currents (O'Gorman et al. 2012). In subtropical meiofaunal communities, an increase of temperature negatively affects species-rich communities, causing the mortality of dominant species, which may have serious consequences for the benthic food web (Gingold et al. 2013). In the deep eastern Mediterranean Sea, global warming has altered the carbon and nitrogen cycles and has had negative effects on deep-sea bacteria and benthic meiofauna in terms of abundance and diversity (Danovaro et al. 2004a). Furthermore, deep-sea meiofaunal secondary production is expected to decrease in many parts of the ocean due to ocean warming (Smith et al. 2008; Mora et al. 2013).

An experimentally induced warming of $4{ }^{\circ} \mathrm{C}$ in coastal sediments showed that heterotrophic variables (bacterial production, meiofaunal biomass, and fluxes of oxygen) respond more clearly to warming than do autotrophic variables (oxygen production, nutrient uptake, and total alkalinity; Alsterberg et al. 2011). Another in situ experiment showed that global warming has also altered body-size population structure, resulting in a disruption in top-down control, whereas eutrophication embodies changes in bottom-up forcing (Jochum et al. 2012). In another mesocosm experiment, the reduction in top-predator body mass enabled the development of a greater intermediate fish predator biomass, and in turn, suppressed key micrograzers (mainly meiofaunal copepods), which led to an overall increase in microalgal biomass (Jochum et al. 2012). Even so, results coming from short- term mesocosm experiments have to be interpreted cautiously, considering that climate change takes place over much longer time scales than ecological mechanisms might compensate for. Several culture experiments showed the strict relationship between temperature and nematode life cycles (e.g., Gerlach and Schrage 1971; Hopper et al. 1973; Warwick 1981b). In general, life cycles become shorter with increased temperature (Gerlach and Schrage 1971; Hopper et al. 1973), and in some cases at low temperatures, nematodes can shift to a vivipary reproduction mode (Gerlach and Schrage 1971). Moens and Vincx (2000) investigated the influence of salinity and temperature on the life history of two estuarine nematode species. They showed that temperature significantly influenced both nematode species, while salinity had relatively minor effects on fecundity and development times, but strongly impacted juvenile viability at the end of the salinity range (0 and 40\%; Moens and Vincx 2000). Furthermore, larger benthic foraminifera (e.g., Amphistegina, Heterostegina), hosting endosymbiotic algae, suffer remarkable bleaching (symbiont or pigment loss) due to temperature-induced stress in culture experiments (e.g., Talge and Hallock 2003; Schmidt et al. 2011).

\section{Response to ocean acidification}

A number of acidification experiments (ex situ and in situ) focusing on meiofauna compartment have been conducted on shallow-water and deep-sea benthic ecosystems (e.g., Barry et al. 2004; Thistle et al. 2006; Ricketts et al. 2009; Fleeger et al. 2010; McIntyre-Wressnig et al. 2013). The intensity of response varies with the distance and intensity of the acidification source (Ricketts et al. 2009). In general, an increase in mortality, combined with a decrease in species richness, is observed (Thistle et al. 2006). In coral reefs, coral bleaching caused by high temperature and increasing acidity led to the replacement of coral reefs by algae and favoured the development of meiofaunal communities on dead corals (HoeghGuldberg et al. 2007). In an experimental mesocosm, acidification led to changes in nematode communities in sediments affected by burrowing urchins (Dashfield et al. 2008). Another experiment proved that acidification had a significant impact on the structure and diversity of nematode communities, especially in sandy sediment nematofauna (Widdicombe et al. 2009). On the other hand, a 56-day $\mathrm{CO}_{2}$ enrichment in a coastal microcosm caused no significant differences in the abundance of total meiofauna (nematodes and harpacticoid copepods; Kurihara et al. 2007). Similarly, fitness and survival of larger benthic foraminifera sampled from reefs were not directly affected by increased partial pressure of $\mathrm{CO}_{2}$ and the concomitant decrease in $\mathrm{pH}$ and calcite saturation states. Nevertheless, a range of non-lethal effects, including partial test dissolution and symbiont loss, was observed (McIntyreWressnig et al. 2013), and several studies have reported the dissolution of calcareous foraminiferal tests in low $\mathrm{pH}$ 


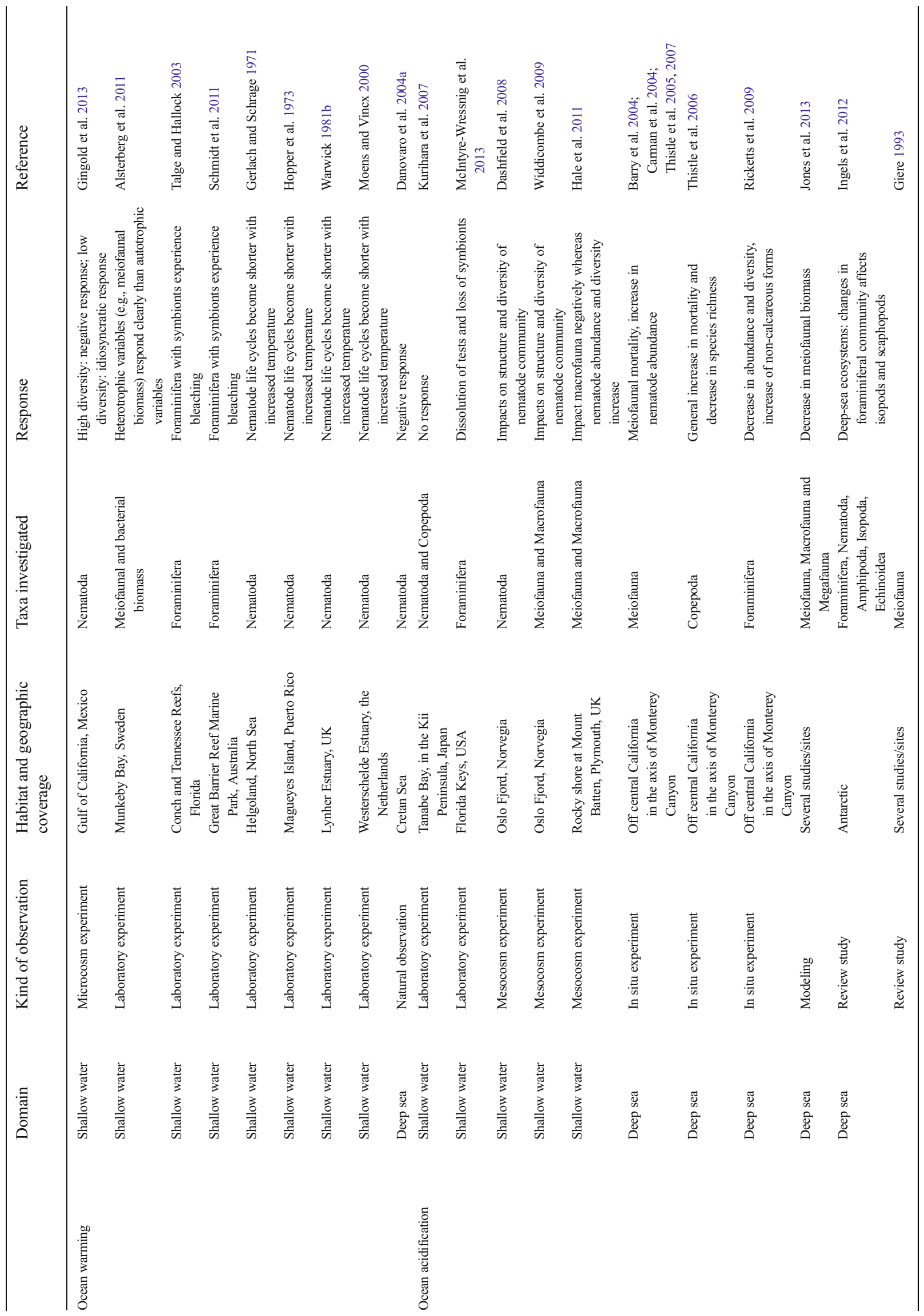




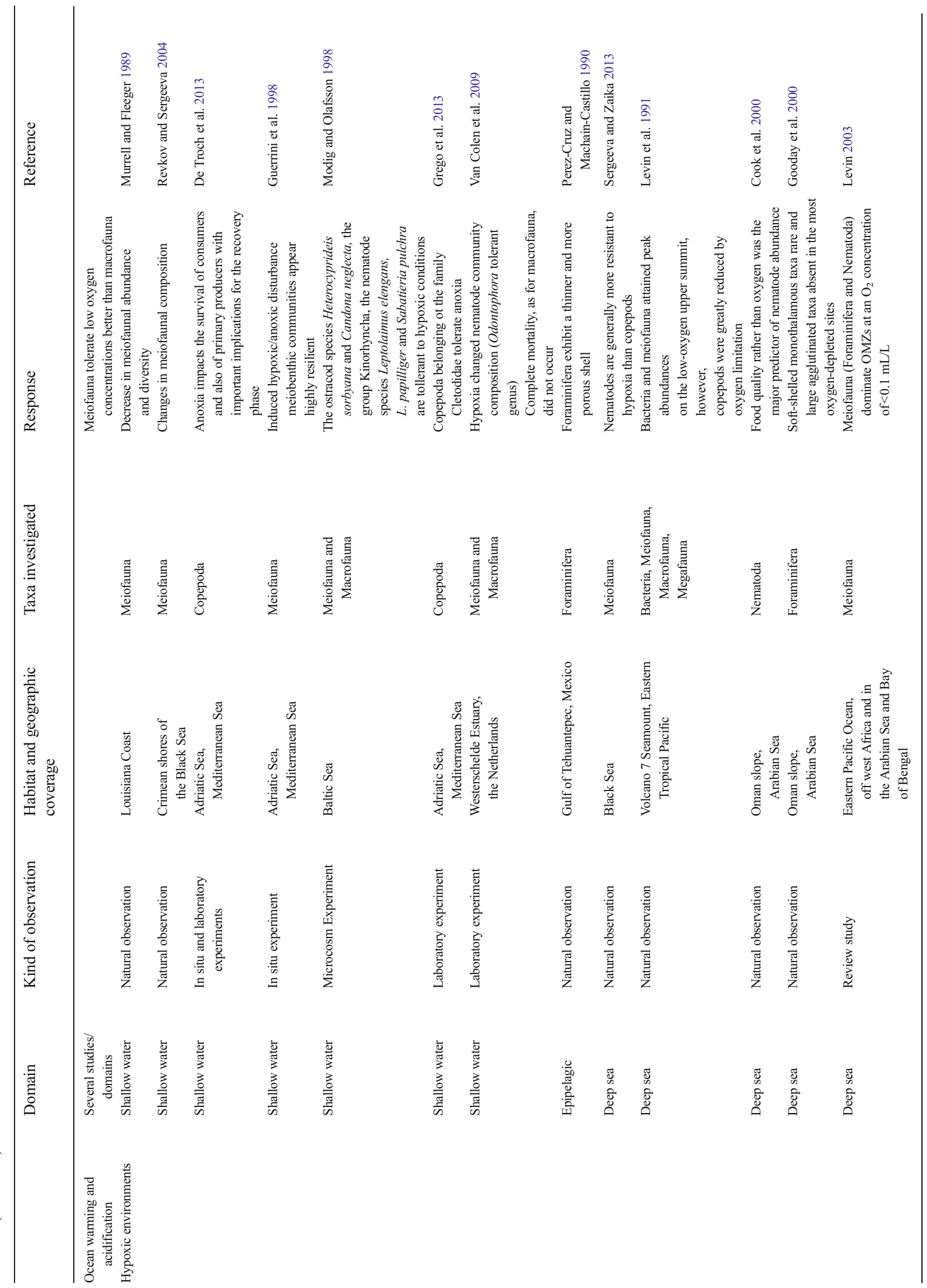




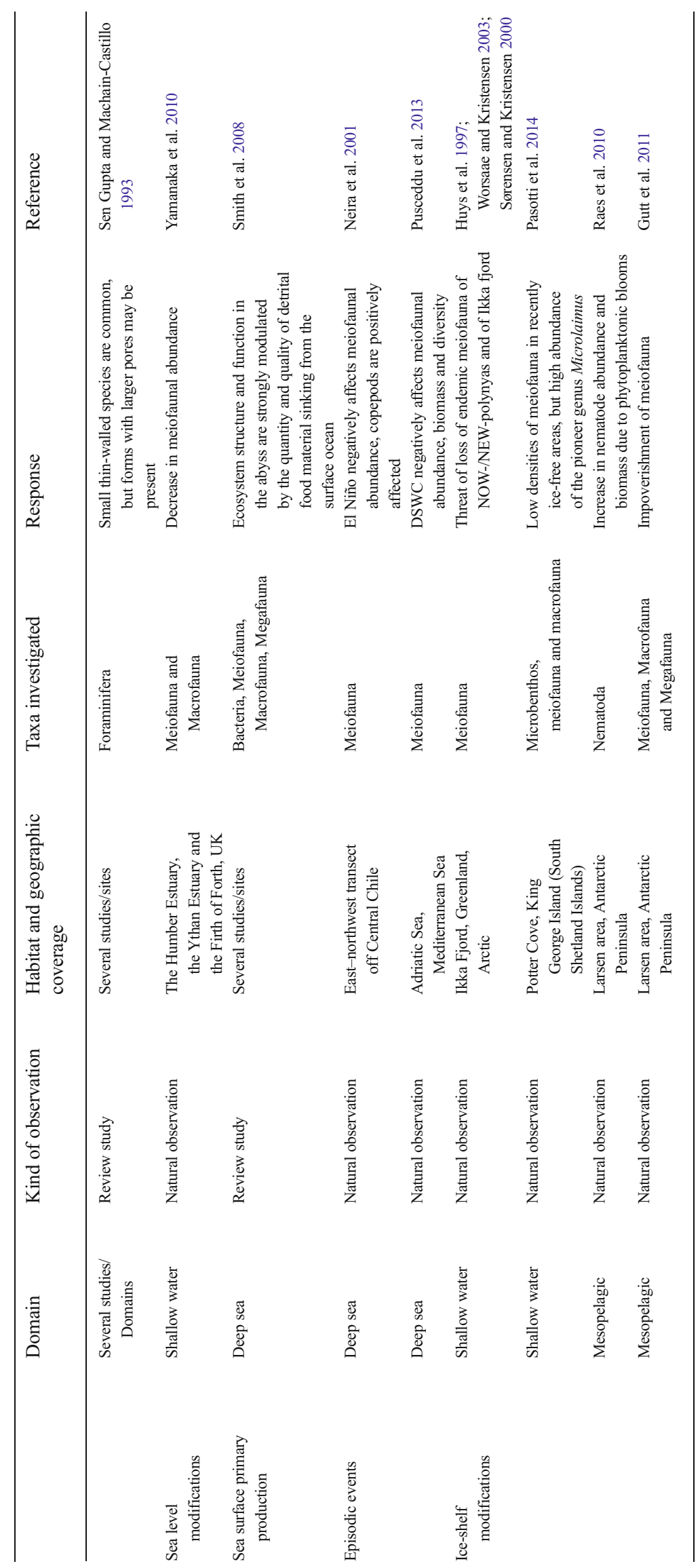




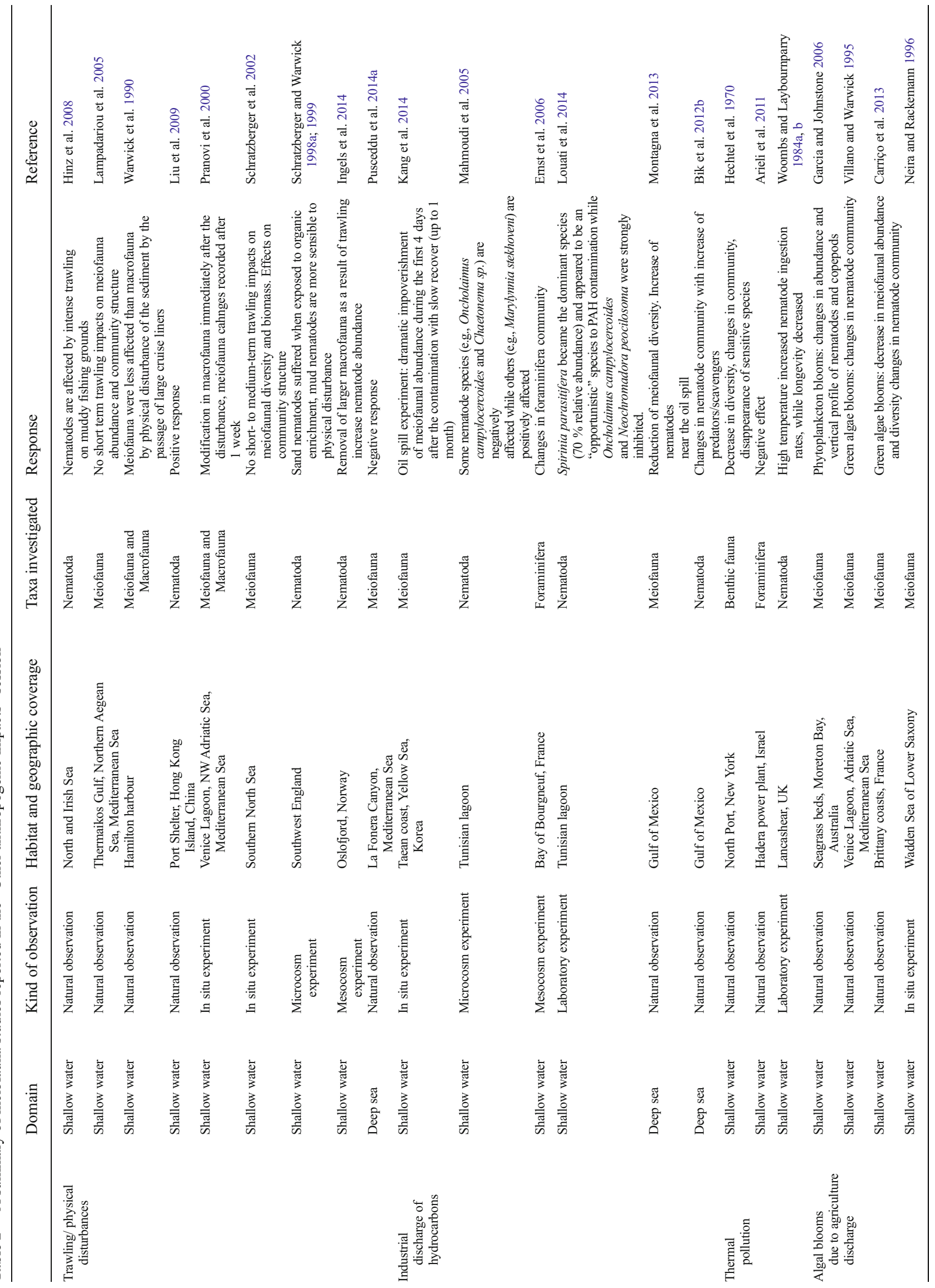




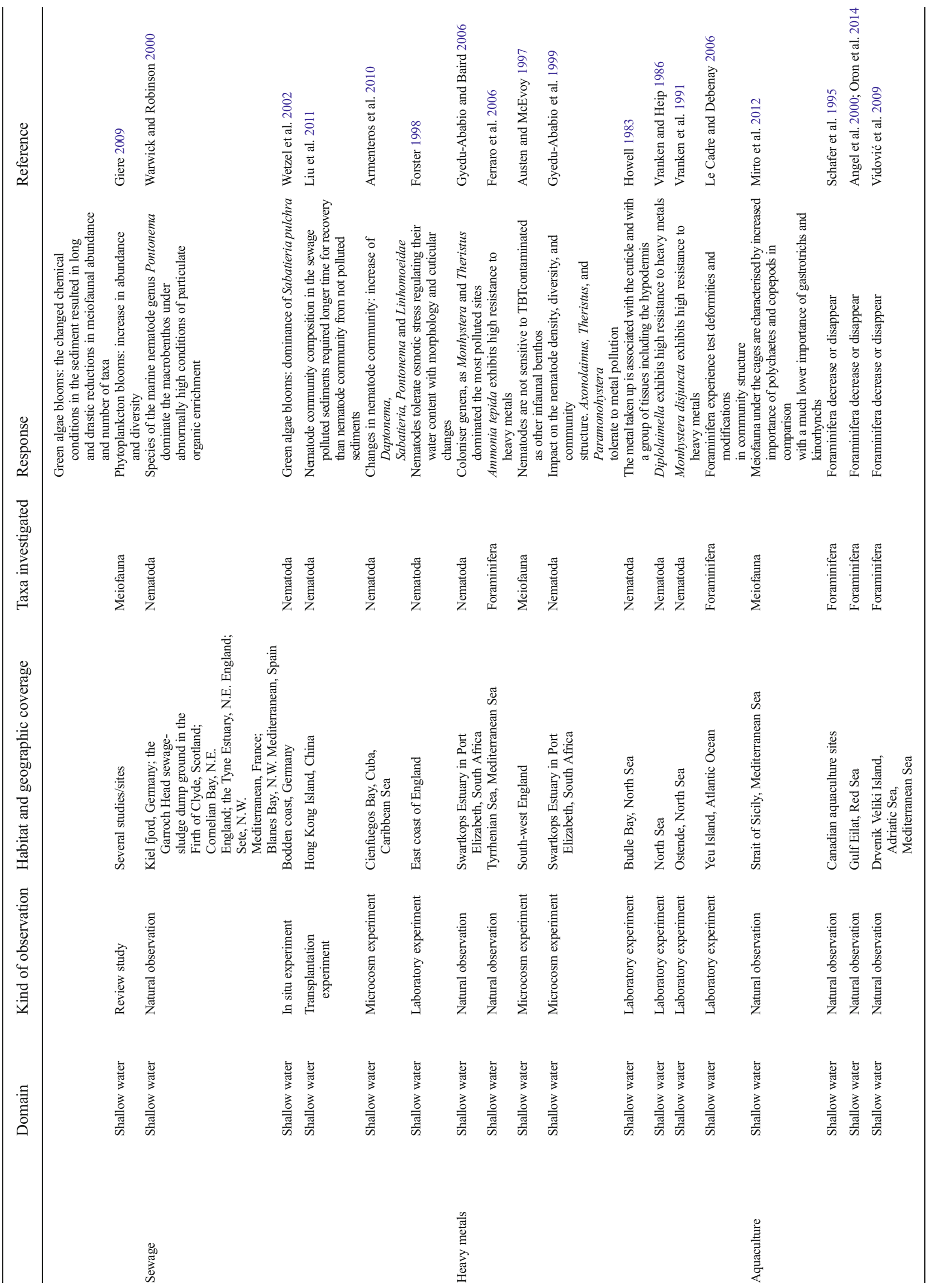




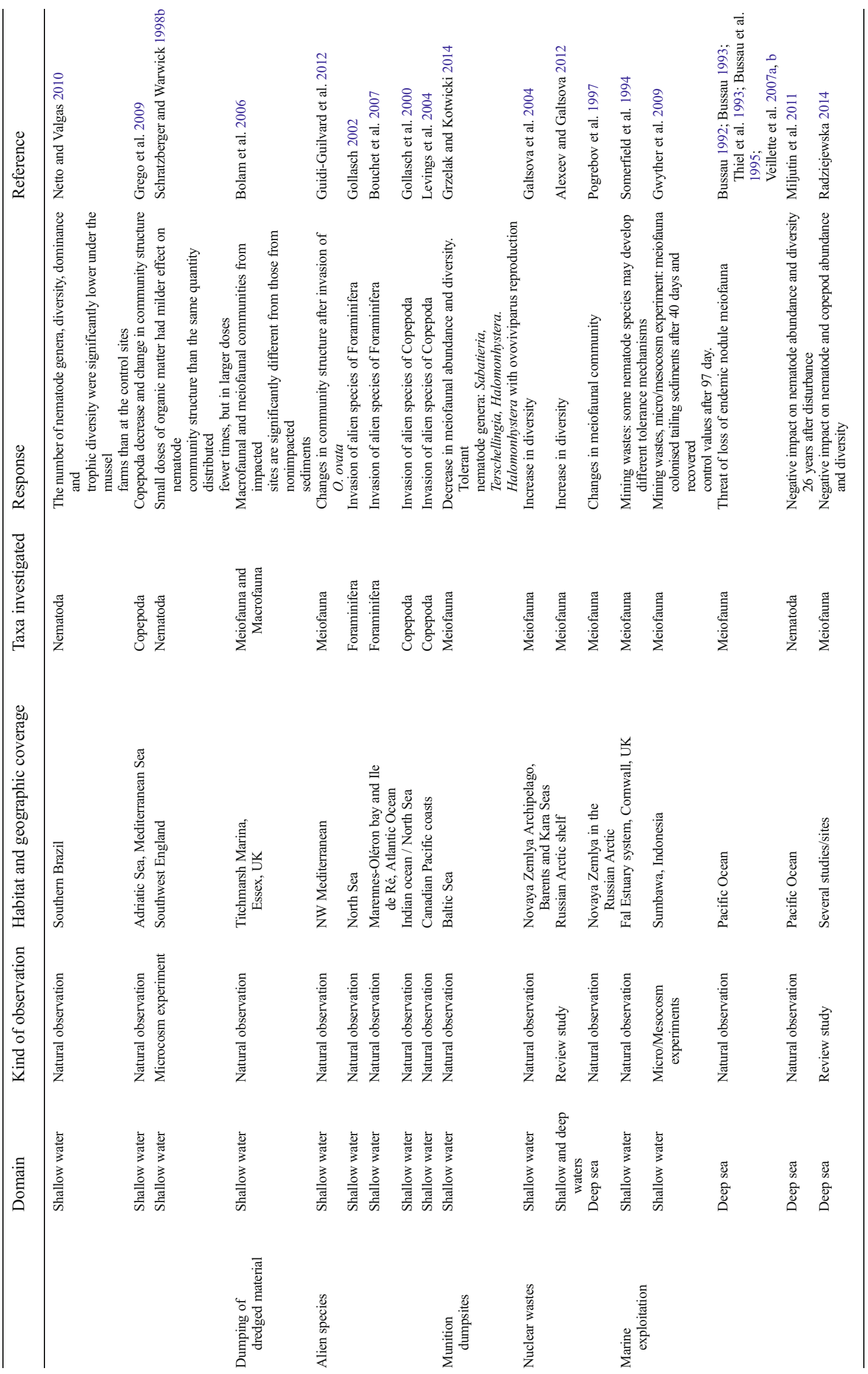


sediments (Green et al. 1993; Mojtahid et al. 2008). In a mesocosm experiment, which combined acidification and warming of the water, the abundance and diversity of macrofauna were negatively affected, while the abundance of nematodes increased due to the reduction in predation and competition (Hale et al. 2011).

Deep-sea sedimentary organisms are expected to be more sensitive to perturbations than are shallow-water ones, because natural deep-sea $\mathrm{CO}_{2}$ concentrations and $\mathrm{pH}$ are less variable than in shallow water (Fleeger et al. 2010). Changes in foraminiferal assemblages due to acifidification may have consequences for specialist predators, such as certain isopods and many scaphopods (Ingels et al. 2012). A series of in situ experiments at $3600 \mathrm{~m}$ off the coast of Monterey Bay (California) were performed by releasing small pools of liquid $\mathrm{CO}_{2}$ to evaluate the potential impacts of a large scale deep-sea carbon dioxide storage program on benthic deep-sea communities (Barry et al. 2013). The results showed that meiofauna experienced high mortalities after exposure to episodic $\mathrm{pH}$ changes (Barry et al. 2004; Carman et al. 2004; Thistle et al. $2005,2006,2007)$. These changes may lead to a decline in meiofaunal biomass, although the decrease is likely to be less than that for larger size classes (macrofauna and megafauna; Jones et al. 2013). These experiments also showed the dissolution of calcareous foraminiferal tests leading to a decrease in the total number of foraminifera and species richness and an increase in the relative abundance of non-calcareous (agglutinated) forms (Ricketts et al. 2009).

\section{Response to ocean deoxygenation}

Because oxygen solubility is inversely correlated with temperature, global warming is already leading to a reduction in oceanic oxygen concentrations (Matear and Hirst 2003). Global warming intensifies hypoxia in OMZs and leads to geographical expansion of existing OMZs; for example, in the eastern Pacific and the Arabian Sea (Stramma et al. 2012). An increase in the number of OMZs is expected in the future (Stramma et al. 2012). In deeper waters, naturally occurring OMZs are located mainly in the eastern Pacific, the Arabian Sea and the Bay of Bengal (Helly and Levin 2004), and they harbour organisms that are adapted to low levels of oxygen..

Prolonged exposure to hypoxic conditions affects the entire meiofaunal community (Wetzel et al. 2001; Sergeeva and Zaika 2013). Meiofauna appear to better tolerate low concentrations of oxygen than macrofauna (Giere 1993). In the core OMZ regions, where oxygen concentrations typically drop below $0.1 \mathrm{~mL} / \mathrm{L}$, the fauna is primarily made up of small organisms, dominated by foraminifera and nematodes (Levin et al. 1991; Levin 2003; Gooday et al. 2009b), while macrofaunal organisms are rare or absent (Levin et al. 1991; Gooday et al. 2000, 2009a, 2009b; Levin 2003). Behavioural (escape, predation reduction) and physiological responses (growth rate decrease, dormancy, initiation of anaerobic metabolism) to hypoxic conditions have been recorded in meiofauna (Rabalais et al. 2002), with a general decrease in meiofaunal densities due by the disappearance of many species (Diaz and Rosenberg 1995). This trend was also noticed in the Gulf of Mexico, where a dramatic decrease in meiofaunal abundance and biomass was detected in association with hypoxia and anoxia events (Murrell and Fleeger 1989). Furthermore, meiofaunal composition can modify according to changes in the hypoxic zone (Revkov and Sergeeva 2004). However, in an OMZ on the Oman slope (Arabian Sea), Cook et al. (2000) showed that food quality rather than oxygen was the major predictor of nematode abundance, highlighting the importance of ecological conditions in hypoxic environments.

In situ experiments confirm natural observations: hypoxia caused a dramatic collapse of the macrofaunal community, while meiofauna survived (Van Colen et al. 2009). Responses to stress vary depending on the species as well as the duration, severity, and frequency of the hypoxic periods (De Troch et al. 2013). In a short incubation time experimental setting, total meiofaunal density was not affected by anoxic conditions, due to the dominance of highly tolerant nematodes (De Troch et al. 2013). In another experimental study on Westerschelde Estuary tidal flats (The Netherlands), hypoxia caused a dramatic change in nematode community composition, with reduced diversity and abundance of all dominant nematodes, except for Odontophora spp. (Van Colen et al. 2009). A field experiment carried out in the Northern Adriatic Sea lagoon showed that nematodes were particularly resistant to the induced hypoxic/anoxic disturbance (Guerrini et al. 1998).

Nematodes are adapted to extreme environments through detoxification strategies and high anaerobic capacity (VeitKöhler et al. 2009; Vopel et al. 1998). As such, they can be used to detect changes in oxygen levels in marine environments. Harpacticoid copepods are the most sensitive meiofauna taxa to low oxygen concentrations (De Troch et al. 2013). Several studies have shown that nematodes are generally more resistant to hypoxia than copepods (Murrell and Fleeger 1989; Modig and Olafsson 1998; Grego et al. 2013; Sergeeva and Zaika 2013). Copepods may stop feeding under anoxic conditions, yielding increased primary producer levels (De Troch et al. 2013). Nevertheless, some eucalanid copepods have a reduced aerobic metabolism that allows them to live permanently in OMZs (Teuber et al. 2013), and some species such as Calanus chilensis show high values of lactate dehydrogenases, which help their transit through OMZs during their daily migration (Teuber et al. 2013). In response to hypoxia, calcareous foraminifera optimise their oxygen capture by becoming smaller (Bernhard and Sen Gupta 1999; Levin 2003), and exhibiting a thinner and more porous shell (Bradshaw 1961; Phleger and Soutar 1973; Perez-Cruz and Machain-Castillo 1990; Sen Gupta and Machain-Castillo 
1993; Gooday et al. 2000). These morphological changes improve oxygen exchange, but make them even more vulnerable to dissolution in the low $\mathrm{pH}$ conditions that prevail in organically enriched OMZs (Gooday et al. 2010). Other likely mechanisms that allow foraminifera to live in hypoxic and anoxic sediments have been reviewed by Koho and PiñaOchoa (2012). They include the presence of bacterial endosymbionts (e.g., Bernhard 2003), the sequestration of chloroplasts (Bernhard and Bowser 1999; Grzymski et al. 2002), the proliferation of peroxisomes and mitochondria (Bernhard and Bowser 2008), and most notably, the respiration of stored nitrates (Risgaard-Petersen et al. 2006; Piña-Ochoa et al. 2010a, b). Denitrification as an alternative metabolic pathway, together with other physiological and ultrastructural adaptations, make foraminifera an important ecological group in oxygen-depleted environments (e.g., Woulds et al. 2007; Gooday et al. 2009a, b; Glock et al. 2012; Koho and PiñaOchoa 2012; Mallon et al. 2012; Fontanier et al. 2014).

\section{Response to changes in sea level and primary productivity}

Rising sea level, by amplifying beach slopes, leads to increased wave exposure and favours the presence of coarser particles in intertidal ecosystems. This causes declines in the abundance of meiofauna and macrofauna, with potential adverse consequences for ecosystem functioning (Yamanaka et al. 2010).

Global warming is likely to have a widespread impact on the benthos through its effect on surface primary productivity, which depends on temperature, depth of the mixing layer, $\mathrm{pH}$, oxygen concentrations and phytoplankton taxa (Wigham et al. 2003; Edwards and Anthony 2004). Deep-sea meiofauna play important roles in the processing and redistribution of food reaching the abyssal seafloor (Rex and Etter 2010). A reduction in the delivery of food to the seafloor linked to warming is likely to lead to reductions in body size, a trend that would favour the meiofauna at the expense of larger size classes (Smith et al. 2008).

\section{Response to increased episodic events}

Global change may also modify the cyclical pattern of climate turbulence, for example, the seasonal 'El Niño' event (Collins et al. 2010). El Niño has led to increased oxygenation of the central Chilean shelf, an area associated with an OMZ, as well as an increase in the supply of organic matter (Neira et al. 2001; Levin 2003). The 1997-1998 El Niño events caused changes in meiofaunal community in an upwelling region off Central Chile: harpacticoid copepod densities were nine times higher than during the previous year, but total meiofaunal densities were $42 \%$ lower (Neira et al. 2001).

Climate change is also expected to increase the intensity and frequency of episodic events in mid-latitude regions of the world (i.e., Mediterranean Sea; Somot et al. 2006; Coma et al. 2009). An example of such events is the dense shelf water cascading (DSWC), particular buoyancy-driven currents causing dense water to rapidly sink into deep basins due to the excess density gained by cooling, evaporation and freezing in the surface layer (Shapiro et al. 2003). A recent study in the Gulf of Lions (Pusceddu et al. 2013) reported that the 2005 DSWC event resulted in lower abundance, biomass and richness of all meiofaunal groups compared with other periods (Pusceddu et al. 2013).

\section{Response to ice-shelf modifications}

Global warming may lead to major changes in polar regions with regard to seasonal changes (ice-cover for example) that may directly affect meiofauna (Kramer et al. 2011). Change in climate is expected to form brackish and saline melt ponds that may provide new habitats for sympagic meiofauna (Jones et al. 2013). On the other hand, the melting of polar glaciers and the resulting glacial melt-water and fine sediments will lead to greater water-column turbidity, affecting phytoplankton production, and increasing sedimentation rates and burial disturbance in coastal regions, particularly fjords (W sławski et al. 2011). Global warming is also responsible for ice-shelf collapse around the Antarctic Peninsula (Scambos et al. 2003). Raes et al. (2010) investigated the effect of this phenomenon on Antarctic meiobenthos. Sea-ice collapse in Larsen continental shelf was associated with a phytoplankton bloom that affected pelagic organisms as well as meiofauna (Gutt et al. 2011), promoting the abundance and diversity of nematodes (Raes et al. 2010). A recent study of Rose et al. (2014) compared meiofauna from Larsen continental shelf stations with food-limited deep-sea stations in the Western Weddell Sea, and showed that meiobenthic communities have not yet recovered from the food-limiting conditions present at the time of iceshelf coverage. In recently ice-free areas close to a glacier in the West Antarctic Peninsula, meiofauna showed relatively low densities. However, the pioneer nematode genus Microlaimus reached high abundance in these newly exposed sites (Pasotti et al. 2014).

However, the largest global warming event will be when the opening Arctic creates polynyas into the open Atlantic Ocean. The New East Water polynya (NEW polynya) has become larger and larger, now reaching $43.000 \mathrm{~km}^{2}$. The whole climate in Northern Europe strongly depends on Arctic polynyas. If both the North East Water polynya (NOW polynya) and NEW polynya collapse, it will affect the Gulf Stream. The unique meiofauna associated with NEW polynya will be endangered, risking extinction (see Huys et al. 1997; Worsaae and Kristensen 2003). The structure of meiofaunal communities inside the unique ikaite tufa columns in the Ikka Fjord is also endangered. These columns are formed by the rare mineral ikaite (calcium carbonate hexahydrate, see Buchardt et al. 


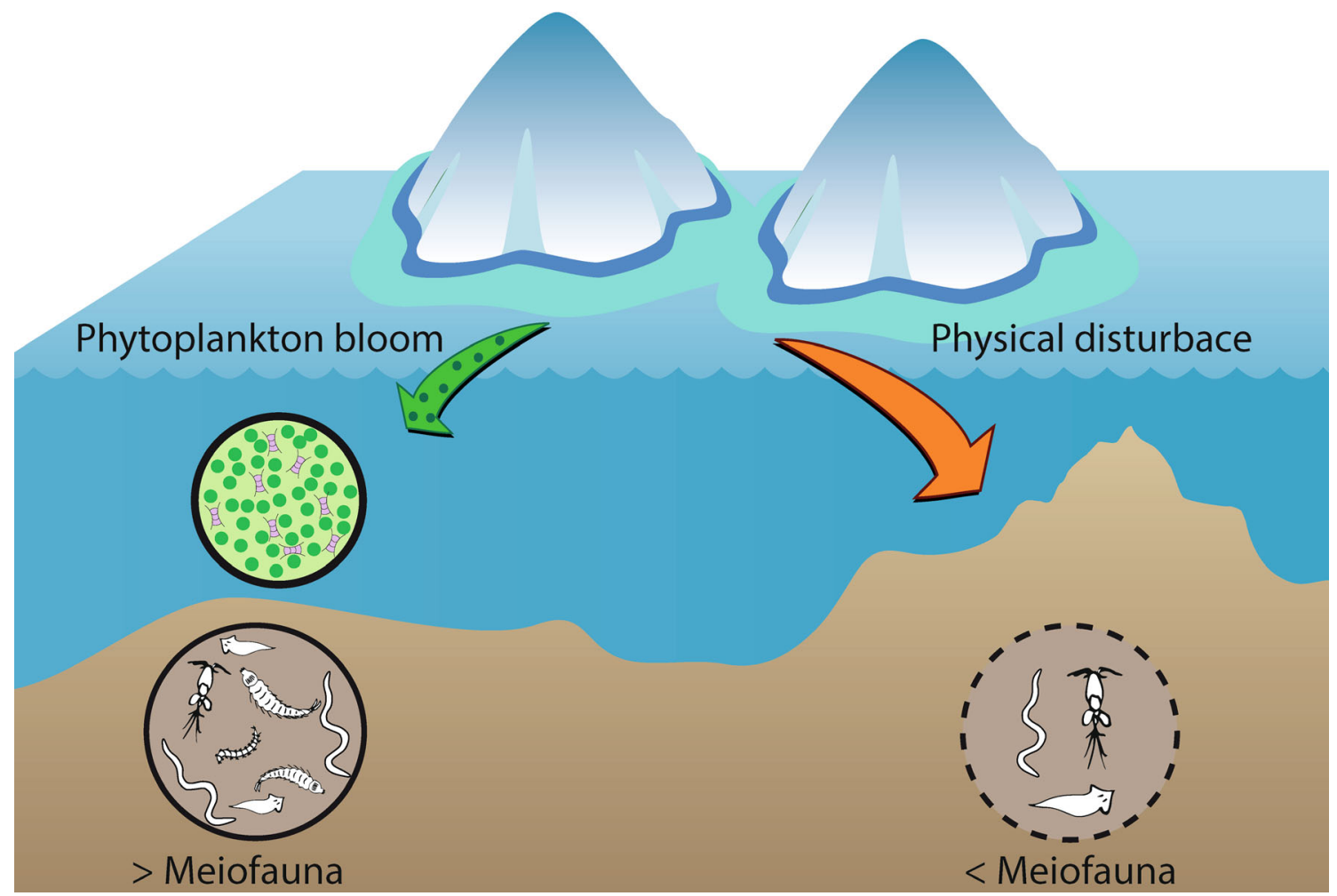

Fig. 2 Diagram of ice-shelf modification impacts on marine meiofauna

1997). The mineral ikaite is metastable, and the ikaite columns are already melting at a temperature of $6{ }^{\circ} \mathrm{C}$ (Buchardt et al. 1997). Meiofauna organisms are found both inside and outside the columns. In particular, a species-rich meiofauna community was described in the Atoll depression, including rotifers, kinorhynchs and eutardigrades (Halobiotus crispae), as well as new species such as the rotifer Notholca ikaitophila (Sørensen and Kristensen, 2000). The ikaite is only stable in water below $6{ }^{\circ} \mathrm{C}$ and the rising temperature is at risk of disintegrating the Ikka fjord and consequently its unique meiofauna community. A diagram of ice-shelf modification impacts on marine meiofauna is given in Fig. 2.

\section{Meiofaunal organisms as useful test case of climate change studies}

Experimental and modelling approaches are used to identify and predict ecosystem level changes in response to climate change (Wernberg et al. 2011). Regarding climate change effects in Antarctica, Ingels et al. (2012) provided a data synthesis on five important benthic taxa (Nematoda, Foraminifera, Isopoda, Amphipoda, Echinoidea). This study shows that foraminifers, in particular species with calcareous tests, are likely to be negatively impacted by ocean acidification, while nematode abundance may be stimulated by high concentrations of $\mathrm{CO}_{2}$ and low $\mathrm{O}_{2}$. Data on benthic macrofauna and meiofaunal nematode diversity from the shelf margin of the North Pole suggest that both local $(\alpha-)$ and turnover ( $\beta-)$ diversity may be determined by ecological conditions (reported as food supply, sediment properties, disturbance, flow and bottom-water oxygen content; Renaud et al. 2006).

Some meiofauna groups, such as foraminifers and ostracods, can be very useful to the study of past climate change by the recovery of their fossil shell. For an exhaustive review on this matter, please refer to paleoclimatology studies. Benthic foraminifera, particularly species with calcareous tests, have a superb fossil record and are widely used by micropaleontologists to reconstruct conditions in the historical and geological pasts (Gooday 2003; Jorissen et al. 2007; Gooday et al. 2009a; Schönfeld et al. 2012). Their utility in palaeoceanography and palaeoecology is based on a considerable body of available knowledge regarding the adaptation of different species to particular environmental conditions (e.g., Murray 2006). The abundance, rapid reproductive rate and ecological sensitivity of species to different environmental conditions also makes foraminifera excellent candidates for monitoring the status of modern ecosystems, particularly those exposed to human impacts (Alve 1995; Mojtahid et al. 2008; Schönfeld et al. 2012). It is also possible to use foraminifera to reconstruct environmental baseline conditions prior to a disturbance event retrospectively (Gooday et al. 2009a). Bouchet et al. (2012) analysed benthic foraminiferan diversity 


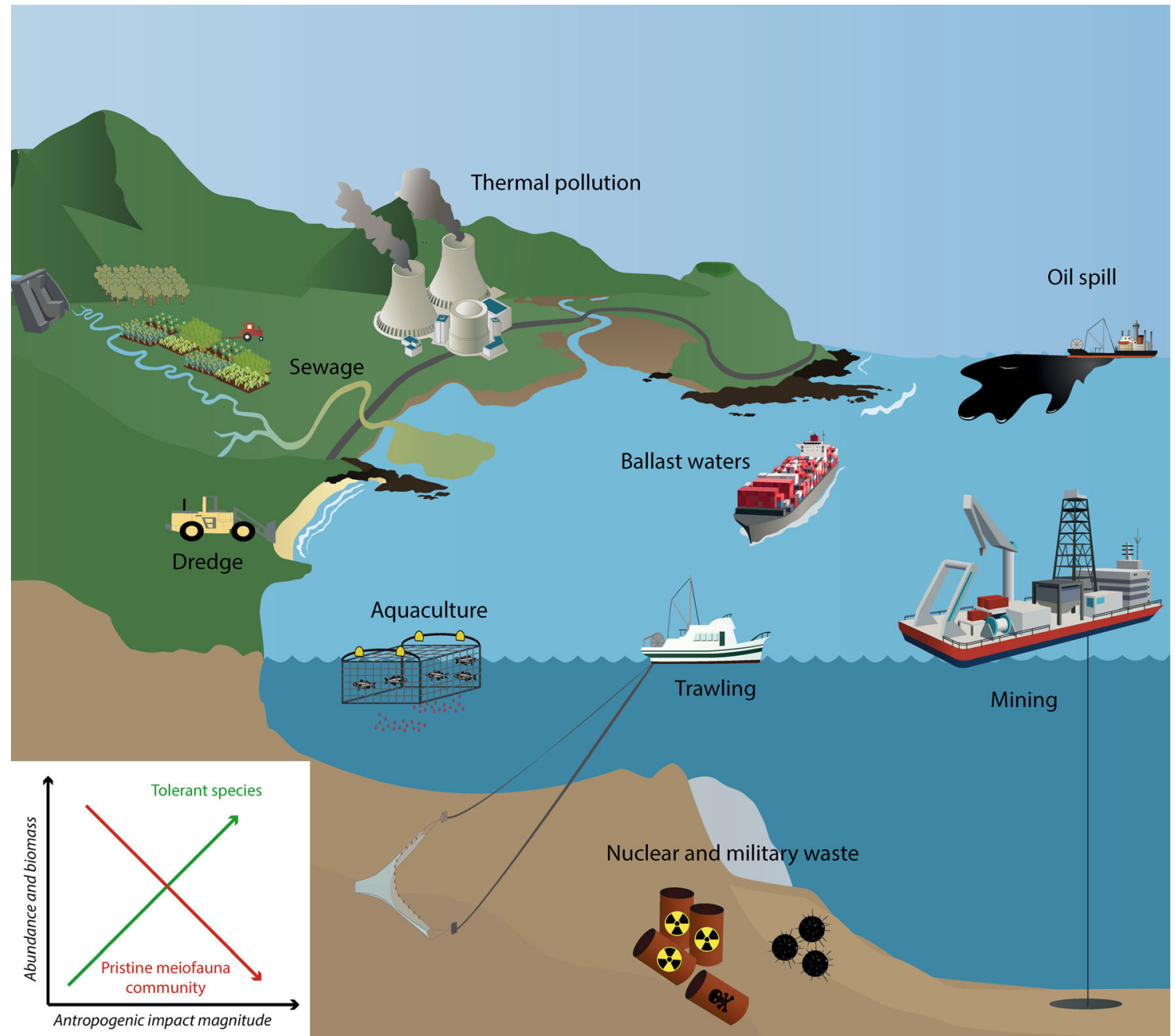

Fig. 3 Diagram of anthropogenic impacts on marine meiofauna

in the top 1-cm layer of sediments with respect to a bottom water oxygen gradient on the Norwegian Skagerrak coast, and established a clear pattern of "bad" to "high" Ecological Quality status (EcoQs). The correlation between bottomwater oxygenation and foraminiferal diversity suggests that benthic foraminiferal represent an efficient bio-monitoring tool to evaluate the EcoQS, a result already evident from OMZs studies (Gooday et al. 2000, 2009b). The Ostracoda fossil record is of greatest value for tracing palaeo-climate events, providing valuable information on past water salinity, temperature and chemistry, hydrodynamic conditions, substrate characteristics, climate, sea level variations, oxygen and nutrient availability (Frenzel and Boomer 2005) and anthropogenic influences (Irizuki et al. 2015). Yasuhara et al. (2012a, 2014) used ostracod and foraminiferal fossil records from the last 250,000 years on the Shatsky Rise in the North Pacific Ocean to demonstrate that rapid climate changes affect deep-sea benthic diversity. They observed glacial-interglacial shifts in overall abundances and species diversities for both meiofauna taxa. Ruiz et al. (2004) described the recent evolution of the Odiel Estuary (SW Spain) during the past decades and the influence of natural and anthropogenic factors analysing the distribution of Ostracoda and Foraminifera.

Richmond et al. (2007) modelled the effects of environmental variability on copepods using a 98 -year salinity record for coastal South Carolina. This study showed that a greater frequency and magnitude of extreme events, such as precipitation and estuarine salinity reduction, negatively affect copepod population growth rates, with possible population declines. Since they represent an important food source for higher trophic levels, the reduction of the harpacticoid population may affect many other estuarine species, as well as species from other habitats whose larval stages develop in the estuary (Richmond et al. 2007).

\section{Other anthropogenic impacts}

It has been demonstrated that meiofauna, including foraminifera, are good indicators of the health of coastal marine 
ecosystems (Vassallo et al. 2006; Balsamo et al. 2012; Schönfeld et al. 2012; Moens et al. 2014). In recent decades, a growing body of scientific literature has been dedicated to the response of meiofauna to anthropogenic impacts, such as pollution (Coull and Chandler 1992; Fleeger and Carman 2011; Balsamo et al. 2012; Moens et al. 2014). Meiofauna reflect changes derived from environmental disturbance, both spatially and temporally (Moreno et al. 2008), and can be considered a collective indicator of environmental quality since they display specific responses to different types of anthropogenic disturbance (Schratzberger and Warwick 1999; Danovaro et al. 2004b). Furthermore, the study of meiofauna is cost-effective compared with that of other benthic components (Rogers et al. 2008). These advantages favour the use of meiofauna as bioindicators, especially when the disturbance source has not been identified (Kennedy and Jacoby 1999). The diversity and richness of taxa are generally lower in polluted and stressed environments, due to the disappearance of more sensitive groups (e.g., ostracods, gastrotrichs, hydrozoans, tardigrades), leaving an assemblage dominated by tolerant organisms, such as nematodes (Pusceddu et al. 2007). The nematode/copepod ratio can be used as a tool to monitor organic pollution (Raffaelli and Mason 1981; Sandulli and De Nicola 1989) in intertidal and subtidal studies (Warwick 1981a; Amjad and Gray 1983; Sheills and Anderson 1985). For example, this biomonitoring index was applied in sediments affected by aquaculture wastes (Sutherland et al. 2007; Riera et al. 2011, 2012). The debate about the difficulty in the interpretation of this index (Coull et al. 1981; Lambshead 1984) was recently resolved by Sun et al. (2015). The incorporation of this index with environmental variables gives reliable information about anthropogenic disturbances (Sun et al. 2015). Alve (1995) provides a thorough review of the effects of different forms of pollution on benthic foraminifera. Thus, the "FORAM" (Foraminifera in Reef Assessment and Monitoring) Index (FI) assesses coral reef vitality and suitability of benthic environments for communities dominated by symbiotic algal organisms (Hallock et al. 2003). Ostracods respond to pollution-induced environmental changes showing high sensitivity to heavy-metal pollution, oil discharges and anoxic conditions (Ruiz et al. 2005). Some ostracod species are adapted to hypoxic conditions and can dominate in polluted environments (Alvarez Zarikian et al. 2000; Yasuhara et al. 2012b). In addition to changes in the Ostracoda community, morphological and geochemical changes can also be detected in ostracod shells (Ruiz et al. 2005). A schematic representation of anthropogenic impacts on marine meiofauna is illustrated in Fig. 3.

\section{Trawling and other physical disturbances}

Industrial fishing using bottom trawling is one of the most severe human-derived disturbances to the seafloor (Watling and Norse 1998), and results in a substantial level of mortality among benthic invertebrates (van Denderen et al. 2013). Larger organisms, such as bivalves and crustaceans, suffer high mortality with long recovery times (Kaiser et al. 2006), whereas smaller meiofaunal taxa appear to have higher resilience to these disturbances (Jennings et al. 2001). Most studies have focused on megafauna and macrofauna, and relatively little is known about the impact of bottom trawling on meiofaunal communities (Moens et al. 2014). In general, meiofauna were less affected than macrofauna by physical disturbance, as in the case of sediment modifications due to the passage of large cruise liners (Warwick et al. 1990). For nematodes, trawling has been shown to have either a positive (Pranovi et al. 2000; Liu et al. 2009, 2011), negative (Schratzberger et al. 2002; Hinz et al. 2008) or minor impact on community structure (Schratzberger et al. 2002; Lampadariou et al. 2005). Nevertheless, a recent study showed that chronically trawled areas in the north-western Mediterranean Sea are characterised by significantly reduced meiofaunal abundance $(80 \%)$, biodiversity (50\%), and nematode species richness $(25 \%)$ when compared with non-trawled areas (Pusceddu et al. 2014a). However, a mesocosm experiment suggests that removal or reduced densities of larger macrofauna species as a result of trawling may lead to increased nematode abundance (Ingels et al. 2014). Environmental setting is, once again, a very important factor to be considered in impact studies, as demonstrated by a series of microcosm experiments designed to evaluate the effects of physical and biological disturbance and organic enrichment on nematodes (Schratzberger and Warwick 1998a, 1999). These experiments showed that nematodes inhabiting sand sediments suffered mainly when exposed to organic enrichment, while nematodes from mud sediments were more sensitive to physical disturbance (Schratzberger and Warwick 1998a, 1999).

\section{Industrial discharge of hydrocarbon}

Hydrocarbon pollution from maritime transport, offshore production, release of refined fuel or accidents can impact marine ecosystems (Arieli et al. 2011; Beyrem et al. 2010; Mahmoudi et al. 2005; Ernst et al. 2006). Hydrocarbons are composed of several types of molecules and can occur in solid, liquid or gaseous forms. These molecules change composition quickly within the first hours of release (Kingston 2002), due to factors such as photoxidation, sedimentation, evaporation and expansion of the oil slick (Ernst et al. 2006). Microbial degradation takes place and can be used as a tool for bioremediation (Schratzberger et al. 2003). Due to these chemical changes, the bioavailability of hydrocarbons may have different effects on benthic fauna, including meiofauna (Alve 1995). Foraminiferal organisms respond to hydrocarbon contaminations by an increase mortality rate and abnormality, and a decrease in density and diversity (Balsamo et al. 2012 and references 
therein). After the sinking of the oil tanker Erika off the French coast, Ernst et al. (2006) studied the response of foraminifera to the presence of oil. Immediately after the accident, Haynesina germanica was the dominant species, but during the first 2 weeks, the authors observed a significant decrease in foraminiferal density compared with control sediments. After 4 weeks, a global density increase was observed, and after 4 months, new foraminiferal species, such as Textularia earlandi and Ammonia spp., dominated. Mahmoudi et al. (2005) added different concentrations of diesel oil to microcosms and compared the meiofaunal communities after 90 days. Nematodes showed a strong decrease in abundance and diversity. Some species, such as Oncholaimus campylocercoides and Chaetonema sp., declined, while others (e.g., Marylynnia stekhoveni) increased with higher diesel concentrations (Mahmoudi et al. 2005). Another controlled oil spill experiment in an intertidal zone was performed in a sandy beach of Korea (Kang et al. 2014). A dramatic impoverishment of meiofaunal abundance was detected during the first 4 days after the contamination, with slow recovery. One month after the contamination, meiofaunal communities recovered their pristine status (Kang et al. 2014).

A study by Montagna and collaborators (2013) investigated the impact of the Deepwater Horizon (DWH) accident in the northern Gulf of Mexico (April 2010, $1525 \mathrm{~m}$ water depth) on meiofauna. This study showed a severe reduction of meiofaunal diversity within $24 \mathrm{~km}^{2}$ from the weelhead. Nematode abundance increased near the oil spill, while harpacticoid copepods decreased drastically, indicating a possible community-level trophic response due to the DWH-spillenriched indigenous bacteria, which would be available as food for deep-sea nematodes (Montagna et al. 2013). Another study in the same area by Bik et al. (2012a) investigated meiofaunal communities prior to and following the oil spill and demonstrated significant changes in community structure, especially for nematodes. Prior to the spill, nematode genera exhibited high richness and evenness, whereas the post-spill communities consisted mainly of predatory and scavenger taxa. Similarly, nematode abundance and diversity significantly decreased with changes in taxonomic structure after contamination by polycyclic aromatic hydrocarbons (Louati et al. 2014). In contaminated sediments that had undergone treatment, biostimulation had a positive impact on community structure and diversity index, suggesting meiofauna as possible candidates for biorestoration of contaminated sediments (Louati et al. 2014). Considering available literature on nematodes affected by hydrocarbon contamination, variable responses have been reported (Balsamo et al. 2012 and references therein). These differences can be explained by different dosages, time of exposure, toxicity and bioavailability of hydrocarbons, together with the types of sediments and hydrodynamic conditions (Balsamo et al. 2012 and references therein). All these parameters are to be taken in account in impact studies concerning meiofauna, and in particular, nematodes.

\section{Thermal pollution}

Hechtel et al. (1970) and Arieli et al. (2011) investigated the impact of thermal pollution on meiofauna due to water discharged from nuclear power plants. Hechtel et al. (1970) focused on benthic invertebrates from Long Beach (USA), reporting a decrease in species diversity and a change of dominant species. These observations reflect the disappearance of sensitive species at high temperatures. Arieli et al. (2011) investigated the impact of thermal pollution along a gradient at the outlet of the Central Hadera (Israel) power plant on foraminiferal communities. Temperatures exceeded $30{ }^{\circ} \mathrm{C}$ during the summer with a dramatic effect on populations, which showed a decrease in abundance and diversity. Species such as $T$. agglutinans were not present at polluted sites, while Lachlanella sp. tolerated high temperatures. The biology of nematodes found in percolating filterbed sewage treatment plants was investigated by Woombs and Laybournparry (1984a, b). Temperature profoundly affected their feeding activity, ingestion rates, growth, reproduction and longevity. As temperature increased, the ingestion rates increased, while longevity decreased with higher temperatures.

\section{Agriculture discharges and sewage}

The increased use of fertilizer in agriculture has resulted in greater export of nutrients to the marine environment. These discharges can have various effects, and may, for instance, trigger green algal blooms that affect marine ecosystems. Algal blooms have a marked influence on the meiobenthos (Garcia and Johnstone 2006) following the deposition of fluffy layers of phytodetritus on the seafloor. These unconsolidated organic deposits, often agglutinated by mucous secretions, enhance microbial activity after relatively short periods (days to weeks), and can subsequently cause a significant increase in meiofaunal abundance and diversity (Giere 2009). Garcia and Johnstone (2006) investigated the impact of filamentous cyanobacterium Lyngbya majuscula blooms on the meiobenthos. A bloom led to oxygen depletion in sediments, causing a decrease in abundance and in their sediment depth distribution. However, the bloom did not affect the abundance and distribution of polychaetes as strongly as it did for copepods and nematodes. Green algae in the genus Enteromorpha are the main cause of the formation of reduced surface sediments or "black spots" on the tidal flats of the Wadden Sea (The Netherlands) (Neira and Rackemann 1996), leading to severe reductions of meiofaunal abundance and diversity (Neira and Rackemann 1996; Carriço et al. 
2013). In an investigation of the impact of green tides on meiofauna on the Brittany coasts, a reduction in diversity and differences in species composition were recorded when comparing impacted and unimpacted beaches (Carriço et al. 2013). Similarily, in the Venice Lagoon (Italy), the communities at sites affected by the green alga Ulva rigida were different from those found in unimpacted sites (Villano and Warwick 1995). Drifting macroalgal mats frequently accumulate during the summer on Baltic Sea beaches, inducing anoxic and sulphidic conditions and leading to changes in meiofaunal composition. In particular, the nematode assemblages under the mats are characterised by low diversity and are dominated by the deposit feeder Sabatieria pulchra (Wetzel et al. 2002). Field studies show shifts in community structure and lower diversity in sites affected by sewage pollution (Coull and Chandler 1992). Experimental studies showed that nematodes can tolerate osmotic stress, regulating their water content by changes in their cuticlea (Forster 1998). Some nematode genera (such as Daptonema, Sabatieria, Pontonema, and genera of the family Linhomoeidae) are particularly abundant in organically enriched locations (e.g., Warwick and Robinson 2000; Armenteros et al. 2010). Copepods showed endocrine alterations while in contact with released anthropogenic chemicals such as insecticides (Dahl and Breitholtz 2008).

\section{Heavy metal pollution}

Heavy metals are naturally present in both terrestrial and marine soils. Among heavy metals, some, such as iron, are essential for biological processes (Wang et al. 2014). However, at higher concentrations, specific elements, including copper, zinc or lead, can be toxic (Baize 1997). The inputs of heavy metals in the marine environments are mainly due to industrial activities. Paint factories, steel mills and waste dumps are all anthropogenic sources of heavy metals (Hack et al. 2007). Several studies have shown a decrease in meiofaunal diversity due to heavy metal pollution in coastal systems (Austen and McEvoy 1997; Gyedu-Ababio and Baird 2006). Some species disappear; others can become dominant (Hack et al. 2007). Copper seems to have the greatest impact on the structure of freshwater benthic communities (Burton et al. 2001). Tolerance to metal pollutants has been shown to vary widely among nematode species (Moens et al. 2014 and references therein). A study about the impact of heavy metals on nematodes from the Swartkops Estuary (Port Elizabeth, South Africa) revealed that nematode community structure was significantly impacted, with dominance of Monhystera and Theristus coloniser genera in the most polluted sites (Gyedu-Ababio et al. 1999). Some species, such as Enoplus communis, show low tolerance to metals (Howell 1983), while others, such as Diplolaimella dievengatensis and Halomonhystera disjuncta nematodes (Vranken and Heip 1986; Vranken et al. 1991; Gyedu-Ababio and Baird 2006), as well as copepods (Burton et al. 2001), can be tolerant to high levels of heavy metals. Nematodes can accumulate and tolerate higher levels of copper, cadmium, zinc and lead than other meiofaunal organisms (van der Wurff et al. 2007 and references therein). However, changes in nematode genetic diversity can be induced by sublethal concentrations of metals (Derycke et al. 2207), and sublethal effects can be detected by life-history parameters, such as fecundity and development times (Vranken et al. 1991). Nematodes mainly store heavy metals in their subcutaneous tissue (Howell 1983) and gastrointestinal tract (Harvey and Luoma 1985), but they can also accumulate heavy metals in their mucus (Riemann and Schrage 1978; Jensen 1987; Decho 1990). Offshore nematode communities appear to be more susceptible to metals than near-shore communities (Austen and McEvoy 1997). High levels of heavy metals potentially generate test deformities in benthic foraminifera and modify community structure (e.g., Alve 1995; Ruiz et al. 2004; Armynot du Châtelet et al. 2004; Ferraro et al. 2006; Le Cadre and Debenay 2006). In an experimental study, Alve and Olsgard (1999) found that foraminifera were able to colonise sediments that were severely contaminated with copper. At high (967-977 ppm) and very high (1761-2424 ppm) concentrations, their abundance decreased and equitability increased. However, there was no effect on overall species richness, and in contrast to previous studies, there was no evidence of increased test deformation (Alve and Olsgard 1999).

\section{Aquaculture}

Aquaculture (i.e., farming of aquatic organisms such as fish, molluscs, crustaceans and aquatic plants, etc.) has rapidly expanded during the last decades in response to the depletion of natural fish stocks by overfishing (Jackson 2001). Under the cages used in fish farming, organic matter accumulates continuously and in great quantities due to the sedimentation of fish wastes (faeces and uneaten food). The accumulation of inorganic material causes eutrophication, which can lead to the development of anoxic sediments (Newell 2004). Aquaculture leads to changes in sediment composition that can impact benthic communities. This enrichment decreases with increasing distance from the cage (Mazzola et al. 1999; Forchino et al. 2011). Several studies have examined the impact of aquaculture on meiofauna (Sutherland et al. 2007; Mirto et al. 2010; Netto and Valgas 2010; Mirto et al. 2012). The enriched habitats are characterised by high densities of meiofaunal opportunistic nematodes and copepods able to utilise a wide variety of food resources (Warwick 1987). In particular, bacterial feeder nematodes can contribute to enhance the rate of bacterial decomposition of the detritus (Warwick 1987). A microcosm experiment showed that an increasing amount of organic matter has a negative effect on nematode diversity. The same concentration of organic matter given in many small quantities had milder effects on community 
structure than when administered in fewer but larger quantities (Schratzberger and Warwick 1998b). In Mediterranean Sea fish farms, a strong effect on meiofaunal density and diversity is observed in sediments under the cages (Mirto et al. 2012). The abundance of some groups (i.e., kinorhynchs) decreases significantly or even disappears in the sediments under the cages, while others (i.e., polychaetes) increase in sediment with higher organic matter content (Mirto et al. 2012). A decrease in the abundance of some meiofaunal groups under the cages was also observed in salmon farms in Canada (Sutherland et al. 2007), and in mussel farming in Brazil (Netto and Valgas 2010). In a North Adriatic (Mediterranean Sea) fish farm, a different copepod community, also characterised by low abundance, was observed in the sediments under the cages (Grego et al. 2009). Studies comparing intensive and semi-intensive farming showed that low intensity farming does not impact on meiofauna community (Danovaro et al. 2004b). A number of studies have also analysed foraminiferal assemblages influenced by organic enrichment from fish farms (e.g., Schafer et al. 1995; Angel et al. 2000; Vidović et al. 2009), as well as the recovery of assemblages after the farming activity ceased (Oron et al. 2014). High population densities are associated with zones that are less severely impacted. These dense populations are dominated by species typical of organically enriched habitats. Recently, Pawlowski et al. (2014) used a next-generation metabarcoding approach (DNA and RNA) to evaluate foraminiferal diversity responses to organic enrichment associated with fish farms. This study revealed high variation among foraminiferal communities collected in the vicinity of fish farms and at distant locations, with evidence for species richness decreasing at impacted sites, especially visible in the RNA data.

\section{Dumping of dredged material}

Dredging and dumping of dredged material are a result of increasing human activities in coastal areas. The dumping itself has consequences for the water column and the seabed. In the water column, the main effects concern changes in turbidity, which can initiate changes in primary production and the release of materials, such as contaminants and organic matter. Sediment inputs to the seabed can also lead to smothering of the fauna, and may initiate changes in bathymetry (Engler et al. 1991). Therefore, dredged material can represent a potential resource to create and/or improve intertidal habitats (i.e., beneficial use; Bolam et al. 2006). It can also initiate an influx of organisms from other regions, especially when the fauna in the dredging area is different from that of the dumping area (Van Hoey et al. 2011). In south-eastern England, 3 years after dredging, meiofaunal and macrofaunal communities rapidly recolonised sediments (Bolam et al. 2006). After 3 months, macrofaunal and meiofaunal assemblages were rich and diverse, despite the presence of sediments with physico- chemical characteristics different from those found in surrounding areas (Bolam et al. 2006). This study also supported the hypothesis that meiofaunal recolonisation occurred primarily through the direct transfer of individuals, i.e., the settlement of a small number of meiofaunal organisms passively re-suspended in the discharged material. A study on the Belgian coast, comparing nematode communities after sand extraction and 2 years later, showed that nematode community composition was more stable after 2 years than at the extracted sites (Vanaverbeke and Vincx 2008).

\section{Introduction of alien species}

Ballast water discharges by ships can have a negative impact on marine ecosystems and also on meiofauna. Ostreopsis ovata, a dinoflagellate non-toxic epiphytic species commonly found in the tropics (Gallitelli et al. 2005), was introduced into Mediterranean Sea via ballast waters (Guidi-Guilvard et al. 2012). This species develops on the brown alga Halopteris scoparia under optimal conditions and becomes toxic (Guidi-Guilvard et al. 2012). Analyses showed that high concentrations of $O$. ovata are associated with changes in the community structure of the phytal meiofauna. Gollasch (2002) recorded non-native foraminiferal species transported in ballast tank sediments from ships sailing into German ports. Along the French Atlantic coast, Bouchet et al. (2007) documented the occurrence of Quinqueloculina carinatastriata, a foraminiferal species that was likely introduced from the Mediterranean and Red Seas by mariculture trade or shipping activities. The survival of tropical plankton organisms in ballast waters was studied by accompanying a container vessel on its 23-day voyage from Singapore to Bremerhaven in Germany (Gollasch et al. 2000). For two tanks, one filled off Singapore and the other off Colombo, Sri Lanka, their phytoplankton and zooplankton content was monitored with daily sampling. As reported in previous studies, species abundance and diversity, especially of zooplankton, decreased sharply during the first days, and only a few specimens survived the whole cruise. The contents of the Colombo tank, however, changed dramatically during the last week of sampling. The harpacticoid copepod, Tisbe graciloides, increased in abundance by a factor of 100 from 0.1 to $10 \mathrm{ind} / \mathrm{L}$ within a few days. This was the first time that a species found in ballast water multiplied at such a high rate. Opportunistic species such as $T$. graciloides are apparently able to thrive and propagate in ballast water tanks under certain conditions. Ballast water tanks may thus serve as incubators for certain species (Gollasch et al. 2000; Levings et al. 2004).

\section{Munition and nuclear waste dump sites}

Chemical munition dump sites are places where weapons and chemical munitions have been dumped. SinceWorld War II, 
thousands of tons of chemical munitions have been dumped into the Baltic Sea (Grzelak and Kotwicki 2014) where meiofaunal communities were poor, not only in terms of abundance, but also in terms of number of taxa (Kotwicki et al. submitted). At dumping sites associated with hypoxic and/or anoxic conditions, the communities are composed of welladapted organisms and dominated by mud-dwelling nematodes like Sabatieria, Terschellingia and Halomonhystera species. Halomonhystera disjuncta showed ovoviviparous reproduction, which secures the survival of the broods (Grzelak and Kotwicki 2014). Sediment burial significantly reduces the toxicity of 2,4,6-trinitrotoluene (TNT) in marine ammunition dumping for the copepod Nitocra spinipes, especially in finegrained sediment (Ek et al. 2007). There is still a remarkable lack of information on the environmental impact of radioactive waste that was disposed of in abyssal oceans in the second half of the 20th century (IAEA 1999). The Barents Sea represents one of the best-known nuclear-polluted marine zones; nuclear tests were carried out in this marine environment by the USSR and nuclear waste has also been dumped there (Galtsova et al. 2004). Pogrebov et al. (1997) showed that meiofaunal communities were different between control and radionuclide-polluted sites. A significant increase in meiofauna diversity was observed at higher concentrations of ${ }^{137} \mathrm{Cs}$ (Galtsova et al. 2004). Alexeev and Galtsova (2012) showed a positive correlation between radio-caesium concentrations and the taxonomic diversity of meiofauna. Furthermore, meiofauna react faster than the macrobenthos to radioactive pollution through changes in diversity and abundance; the macrobenthos is more stable and shows fewer effects in the short term (Alexeev and Galtsova 2012).

\section{Exploitation of mineral resources}

The exploitation of mineral resources has a direct impact on the benthic community due to removal of resources, and also an indirect impact made by shallow-water mining wastes. The effects of shallow-water mining wastes (heavy metals) on meiofauna were investigated in the Fal Estuary system (southwest England), revealing that some nematode species may have developed different tolerance mechanisms to survive in areas with high heavy metal concentrations (Somerfield et al. 1994). Microcosm and mesocosm scale experiments on meiofauna recolonisation in discharges tailing sediments were performed in Benete Bay (Indonesia; Gwyther et al. 2009). This study revealed that meiofauna colonised tailing sediments after 40 days and recovered control values after 97 days.

The deep-sea realm is one of the least-known oceanic areas on Earth, but this remote environment harbours large areas of concentrated metal reserves (Thurber et al. 2014). Many of these metals are used in electronics, and since terrestrial supplies are diminishing, deep-sea mineral resources are likely to be extensively mined within the next few decades (Thurber et al. 2014). We are experiencing an increasing attention on exploration and mining of deep-sea minerals (such as cobaltrich ferromanganese crusts, seafloor massive sulphide deposits and polymetallic nodules). In addition to the physical disturbance due to mineral deposit extraction, the reduction in habitat heterogeneity (Zeppilli et al. 2014) may permanently alter the structure of benthic communities (Leduc et al. 2015 and references therein). Benthic meiofauna from polymetallic nodule areas are known from the Pacific Ocean (Hessler and Jumars 1974; Snider et al. 1984; Renaud-Mornant and Gourbault 1990; Bussau et al. 1995; Ahnert and Schriever 2001; Radziejewska 2002; Lambshead et al. 2003; Veillette et al. 2007a, b; Miljutin and Miljutina 2009a, b; Miljutina et al. 2010, 2011; Miljutina and Miljutin 2012) and Indian Ocean (Parulekar et al. 1982; Ansari 2000; Ingole et al. 2000, 2005; Singh et al. 2014). The techniques used for the extraction of nodules from the seafloor involve mechanical screening, bucket or scraper methods or hydraulic approaches to lift the nodules from the seafloor (Thiel 2003). These techniques can lead to the complete destruction of the upper 5-10 cm layer of soft sediments and the removal of nodules dispersed in the upper sediment layer (Miljutin et al. 2011), killing most meiobenthic organisms inhabiting the upper $0-5 \mathrm{~cm}$ layer of sediments, as well as those colonising the nodules. Chung et al. (2002) summarised the potential impact on benthic fauna during mining activities: (1) direct impact along the track of the nodule collector, where the sediment and associated fauna is crushed or dispersed in a plume, and the nodules are removed, (2) smothering or entombment of benthic fauna by the sediment plume, and (3) destruction of food resources for some species. The nodules themselves constitute a specific habitat for some organisms inhabiting their surface and the interstitial space inside their crevices and internal cavities (Thiel et al. 1993; Veillette et al. 2007a, b). In general, nematodes inhabiting the surface and crevices of nodules differ from the assemblages in the surrounding soft sediments, and some species are exclusively reported only in nodule crevices (Bussau 1993; Thiel et al. 1993; Bussau et al. 1995; Veillette et al. 2007a, b). Surprisingly, Bussau (1992) also found unique tardigrade fauna on and inside the manganese nodules from the Peru Basin at water depths from 4140 to $4170 \mathrm{~m}$. The new genus and three new species he described (Bussau 1992) have never been observed outside the manganese nodule area and may be endemic. However, unless more sampling is undertaken, it cannot be concluded if this is a question of pseudoendemism due to undersampling or if these species are truly endemic to the manganese nodule field, and in this case, if the nodule-associated fauna will also be lost during mining. Experiments conducted on the impacts of nodule mining on abyssal nematode communities in the Clarion-Clipperton Fracture Zone (Tropical and Equatorial Pacific) showed a negative impact on nematode abundance and diversity (Vopel and Thiel 2001). The severity of the impact was demonstrated by 
changes in meiobenthic abundance, presence/absence of key taxa, and species diversity for nematodes and harpacticoid copepods (Radziejewska 2014). The impact remained detectable 26 years after the initial disturbance (Miljutin et al. 2011).

\section{Conclusions and perspectives}

The benthic fauna within an ecosystem have different body size spectra that reflect structural and functional aspects. Marine benthos forms an intricate network in which each group/ species contributes functionally. This review demonstrates that meiofauna, besides being fundamental to understand the structure and functioning of marine communities, can be used as a proxy for responses of benthic communities to environmental changes.

This review shows that meiofauna can be a useful tool to investigate the impacts of climate change. In most studies, global change negatively impacts meiofaunal communities, which experience a reduction of abundance and diversity, with important consequences on benthic food webs. Overall, meiofauna are less negatively affected by climate change than are macrofauna; for example, at very low oxygen concentrations, only meiofaunal organisms survive. Some species of nematodes and foraminifers can even be favoured by the occurrence of extreme environmental conditions. The presence of these "extreme" species can used as warning signal of global change. Some climate impacts, such as ice-shelf modifications, can have opposite effects on meiofauna: negative (by increasing physical disturbances on the seafloor) and/or positive (by creating new habitats and promoting phytoplanktonic blooms). In any case, unique meiofaunal communities such as those found on the NEW polynya and in the Ikka Fjord, are endangered by iceshelf modifications, with the risk of extinction.

Meiofauna are doubtlessly good indicators of anthropogenic impacts, and reflect spatial and temporal changes. However, it is difficult to correctly interpretate meiofaunal responses without information about abiotic factors. Therefore, measurements of associated environmental conditions are fundamental in the interpretation of the observed patterns. Considering environmental parameters together with meiofaunal indices strengthens scientific interpretations and provides useful tools for the detection of anthropogenic disturbances. Multistressor experiments are more informative than single stressor ones, revealing complex changes in ecological and biological interactions, and a precautionary approach may be required when interpreting single stressor studies. Anthropic pollutions generally have a negative effect on meiofauna. However, the increase in sea surface primary production and algal blooms generally has a positive effect on nematode abundance and biomass, and habitat formation such as dumping of dredged material may increase meiofaunal abundance and diversity by locally increasing heterogeneity. As in the case of climate, some species can tolerate polluted conditions and show physiological changes. In addition, several meiofaunal species are specific to a kind of impact and can be used as detection tools. For organic enrichment, it was proved that the partitioning of organic inputs (as for aquaculture) can significantly reduce the impacts on meiofauna. In some ecosystems, the recovery time for the meiobenthic community can be very slow, as in the case of the deep-sea exploitation of minerals where severe habitat destruction may induce a loss of biodiversity over several decades.

Four taxonomic groups are valuable for predicting global changes: foraminifers (especially calcareous forms), nematodes, copepods and ostracods. Foraminifers and copepods are very sensitive to changing environmental conditions, while some nematode species are particularly tolerant to stress. Further studies about global change impact on less represented taxa are thus necessary.

In summary, compared to other benthic groups, meiofauna can be particularly valuable in impact studies. The study of meiofauna is cost-effective compared to that of other benthic components, and their use as bioindicators is particularly useful when the source of disturbance has not been identified, and to identify the effects of different forms of ecosystem perturbations. Nevertheless, meiofaunal taxonomic identification remains a challenge and a lack of experts complicates the task. Identification can be facilitated by using free computer-based illustrated keys that are accessible online (e.g., NEMYS http:// nemys.ugent.be/ for nematodes; http://copepodes.obs-banyuls. fr/en for copepods; Ellis and Messina http://www.micropress. org/em/about.php and World Foraminifera Database http:// www.marinespecies.org/foraminifera/ for foraminifera). The development of molecular approaches is bringing significant help to reinforce taxonomic identification and to distinguish morphologically similar species and cryptic species. These also include the development of rapid molecular methods for the identification "en masse" of small metazoans (Bik et al. 2012b), such as high-throughput next-generation sequencing (Fonseca et al. 2010) and proteomic fingerprinting (Laakmann et al. 2013). This review has elucidated the importance of meiofauna in global change impact studies. There is an urgent need to focus impact research on the taxonomy, genetics and function of keystone meiofaunal taxa or species.

Acknowledgments The authors thank the western France laboratory cluster (Laboratoire d'Excellence) LabexMER (ANR-10-LABX-19), the French Research Institute for the exploitation of the Sea (IFREMER), the Institut Carnot, the Total Foundation, the Océanopolis aquarium, the Zone Atelier Brest Iroise, the Finistère Departmental Council, the University of Western Brittany, the Brest Métropole Océane, the Brittany Regional Council, the European Institute for Marine Studies, the bank CASDEN Banque Populaire: Banque de l'Education, Recherche et Culture, the Banque Populaire de l'Ouest, the platform PERISCOPE and Grenier Photo for financing the MeioScool2013 project: Meiofaunal International Workshop, held in Brest (26-29 November 2013). A group of M1 students from IUEM (Institut Universitaire Européen de la Mer, Brest) participated in the workshop MeioScool reviewing all the studies available on climate change and 
other anthropogenic stressor effects on meiofauna under the supervision of Zeppilli D., Fernandes D. and Thébault J. From their work, the invited speakers and other participants in the workshop participated in generating the manuscript. DZ was supported by LabexMER (ANR-10-LABX-19), co-funded by a grant from the French government under the program "Investissements d'Avenir", by a grant from the Brittany Regional Council (SAD programme) and by the project "Deep-sea hYdrothermal Vent nematodes as potential source of new Antibiotics (DYVA), funded by the Total Foundation and IFREMER.

Open Access This article is distributed under the terms of the Creative Commons Attribution 4.0 International License (http:// creativecommons.org/licenses/by/4.0/), which permits unrestricted use, distribution, and reproduction in any medium, provided you give appropriate credit to the original author(s) and the source, provide a link to the Creative Commons license, and indicate if changes were made.

\section{Glossary}

Bleaching

Deposit feeder

Ecosystem functions/ Ecosystem functioning

Idiosyncratic model
Expulsion of the endosymbiotic algae (zooxanthellae) or their algal pigment from the tissue of symbiotic invertebrates (mainly reef corals), which lose their colour and turn white. Coral can survive a bleaching event, and at times it may be a reversible process, depending on the intensity and extent of the phenomenon. Several factors can cause the bleaching (e.g., increased or decreased light, thermal stress, bacterial infections).

An animal that ingests deposited, particulate material that primarily consists of inert sediments of low food value (mineral grains, refractory organic matter, etc.).

The sum of biological, geochemical, and physical processes that operate within an ecosystem, sustaining the overall performance of the ecosystem and suppling ecosystem services.

The idiosyncratic model suggests that the relationship between species richness and ecosystem functioning results in an extremely variable ecosystem. More specifically, the idiosyncratic relationship implies that each species has a different contribution to ecosystem functioning, depending on its interspecific interactions.
Macrofauna

Meiofauna

Permanent meiofauna

Phytal meiofauna

Rivet model

Sympagic meiofauna

Temporary meiofauna
Benthic animals retained on a 1mm sieve.

Benthic animals passing through a 1-mm sieve and retained on a 20$\mu \mathrm{m}$ sieve.

Organisms that spend their entire life cycle in the meiofauna size category.

Meiofauna living in close association with seagrasses, kelp and seaweeds.

The rivet model is based on the potential overlap and complementarity among the functions of different species. In this model, when a species is removed or added to an ecosystem, its contribution to ecosystem functioning is relatively small. This allows the system to keep the ecological function when a few species are lost.

Meiofauna living in close association with sea ice, either on the ice under-surface, on the soft lower ice layer, within briny channels or pockets in the solid sea ice, or at the interface with water below the sea ice.

Organisms that are part of the meiobenthos only during a stage of their life (i.e., larvae and juveniles stages of macrofauna).

\section{References}

Ahnert A, Schriever G (2001) Response of abyssal Copepoda Harpacticoida (Crustacea) and other meiobenthos to an artificial disturbance and its bearing on future mining for polymetallic nodules. Deep-sea Res Pt II 48:3779-3794

Alexeev DK, Galtsova VV (2012) Effect of radioactive pollution on the biodiversity of marine benthic ecosystems of the Russian Arctic shelf. Polar Science 6:183-195

Aller RC, Aller Y (1992) Meiofauna and solute transport in marine muds. Limnol Oceanogr 37:1018-1033

Alsterberg C, Hulth S, Sundbäck K (2011) Response of a shallow-water sediment system to warming. Limnol Oceanogr 56(6):2147-2160

Alvarez Zarikian CA, Blackwelder PL, Hood T, Nelsen TA, Featherstone C (2000) Ostracods as indicators of natural and anthropogenicallyinduced changes in coastal marine environments. Coasts at the Millennium, Proc 17th Int Conf Coastal Soc, Portland, OR USA 896-905

Alve E (1995) Benthic foraminifera response to estuarine pollution: a review. J Foramin Res 25:190-203

Alve E, Olsgard F (1999) Benthic foraminiferal colonization in experiments with copper contaminated sediments. J Foramin Res 29:14 23 
Amjad S, Gray JS (1983) Use of the nematode-copepod ratio as an index of organic pollution. Mar Pollut Bull 14:178-181

Angel DL, Verghese S, Lee JJ, Saleh AM, Zuber D, Lindell D, Symons A (2000) Impact of a net cage fish farm on the distribution of benthic foraminifera in the northern Gulf Eilat (Aqaba, Red Sea). J Foramin Res 30(1):54-65

Ansari ZA (2000) Distribution of deep-sea benthos in the proposed mining area of Central Indian Basin. Mar Georesour Geotechnol 18: 201-207

Arieli RN, Almogi-Labin A, Abramovich S, Herut B (2011) The effect of thermal pollution on benthic foraminiferal assemblages in the Mediterranean shoreface adjacent to Hadera power plant (Israel). Mar Pollut Bull 62:1002-1012

Armenteros M, Pérez-García JA, Ruiz-Abierno A, Díaz-Asencio L, Helguera Y, Vincx M, Decraemer W (2010) Effects of organic enrichment on nematode assemblages in a microcosm experiment. Mar Environ Res 70:374-82

Armynot du Châtelet E, Debenay J-P, Soulard R (2004) Foraminiferal proxies for pollution monitoring in moderately polluted harbors. Environ Pollu 127:27-40

Austen MC, McEvoy AJ (1997) The use of meiobenthic communities in laboratory microcosm experiments: response to heavy metal contamination. J Exp Mar Biol Ecol 211:247-261

Baede APM, Ahlonsou E, Ding Y, Schimel D (2001) The climate system: an overview. In Houghton JT Ding Y, Griggs DJ, Noguer M, van der Linden PJ, Dai X, Maskell K, Johnson CA (eds). Climate change 2001: The scientific basis. Contribution of working group I to the third assessment report of the intergovernmental panel on climate change. Cambridge University Press, Cambridge, United Kingdom and New York, NY, USA, p 881

Baguley JG, Montagna PA, Lee W, Hyde L, Rowe GT (2005) Spatial and bathymetric trends in harpacticoida (Copepoda) community structure in the northern Gulf of Mexico deep sea. J Exp Mar Biol Ecol 330:327-341

Baize B (1997) Teneurs totales en « métaux lourds » dans les sols Français. Institut National de la Recherce Agronomique

Baldrighi E, Aliani S, Conversi A, Lavaleye M, Borghini M, Manini E (2013) From microbes to macrofauna: an integrated study of deep benthic communities and their response to environmental variables along the Malta Escarpment (Ionian Sea). Sci Mar 77(4):625-639

Balsamo M, Semprucci F, Frontalini F, Dr. Coccioni R (2012) Meiofauna as a tool for marine ecosystem biomonitoring marine ecosystems. In: Antonio C (ed) Marine ecosystems. In Tech, Rijeka, pp 77-104

Bampton M (1999) Anthropogenic transformation. In: Alexander DE, Fairbridge RW (eds) Encyclopedia of environmental science. Kluwer Academic Publishers, Dordrecht

Barron EJ (1989) An editorial. Glob Planet Chang 1(1-2):vii-viii

Barry JP, Buck KR, Lovera CF, Kuhnz L, Whaling PJ, Peltzer ET, Walz P, Brewer PG (2004) Effects of direct ocean CO2 injection on deep-sea meiofauna. J Oceanogr 60:759-766

Barry JP, Buck KR, Lovera CF, Brewer PG, Seibel BA et al (2013) The response of abyssal organisms to low $\mathrm{pH}$ conditions during a series of CO2-release experiments simulating deep-sea carbon sequestration. Deep Sea Res Part II 92:249-260

Bernhard JM, Sen Gupta BK (1999) Foraminifera of oxygen depleted environments. In: Sen Gupta BK (ed) Modern foraminifera. Kluwer Academic Publisher, Dordrecht

Bernhard JM (2003) Potential symbionts in bathyal foraminifera. Science 299:861

Bernhard JM, Bowser SS (1999) Benthic foraminifera of dysoxic sediments: chloroplast sequestration and functional morphology. Earth Sci Rev 46:149-165

Bernhard JM, Bowser SS (2008) Peroxisome proliferation in foraminifera inhabiting the chemocline: an adaptation to reactive oxygen species exposure? J Eukaryotic Microbiology 55:135-44
Beyrem H, Louati H, Essid N, Aissa P, Mahmoudi E (2010) Effects of two lubricant oils on marine nematode assemblages in a laboratory microcosm experiment. Mar Environ Res 69:248-253

Bik HM, Halanych KM, Sharma J, Thomas WK (2012a) Dramatic shifts in benthic microbial eukaryote communities following the deepwater horizon oil spill. PLoS ONE 7(6), e38550. doi:10.1371/journal. pone. 0038550

Bik HM, Sung W, De Ley P, Baldwin JG, Sharma J et al (2012b) Metagenetic community analysis of microbial eukaryotes illuminates biogeographic patterns in deep-sea and shallow water sediments. Mol Ecol 21(5):1048-1059

Bindoff NL, Willebrand J, Artale V, Cazenave A, Gregory J et al (2007) Observations: oceanic climate change and sea level. In: Solomon S, Qin D, Manning M, Chen Z, Marquis M, Averyt KB, Tignor M, Miller HL (eds) Climate change 2007: the physical science basis. Contribution of working group I to the fourth assessment report of the intergovernmental panel on climate change. Cambridge University Press, Cambridge, pp 385-432

Bolam SG, Schratzberger M, Whomersley P (2006) Macro- and meiofaunal recolonisation of dredged material used for habitat enhancement: temporal patterns in community development. Mar Pollut Bull 52:1746-1755

Boldina I, Beninger PG, Le Coz M (2014) Effect of long-term mechanical perturbation on intertidal soft-bottom meiofaunal community spatial structure. J Sea Res 85:85-91

Bonaglia S, Nascimento FJA, Bartoli M, Klawonn I, Brüchert V (2014) Meiofauna increases bacterial denitrification in marine sediments. Nature Comm 5:5133

Bongers T, Ferris H (1999) Nematode community structure as a bioindicator in environmental monitoring. Trends Ecol Evol 14(6): 224-228

Borja A (2014) Grand challenges in marine ecosystems ecology. Front Mar Sci. doi:10.3389/fmars.2014.00001

Bouchet V, Debenay J-P, Sauriau P-G (2007) First report of Quinqueloculina carinatatriata (Wiesner, 1923) (foraminifera) along the French Atlantic coast (Marennes-Oléron bay and Ile de Ré). J Foramin Res 37:204-212

Bouchet VMP, Alve E, Rygg B, Telford RJ (2012) Benthic foraminifera provide a promising tool for ecological quality assessment of marine waters. Ecol Indic 23:66-75

Bradshaw JS (1961) Laboratory experiments on the ecology of foraminifera. Contrib Cushman Foundation for Foraminiferal Res 12:87106

Braeckman U, Vanaverbeke J, Vincx M, van Oevelen D, Soetaert K (2013) Meiofauna metabolism in suboxic sediments: currently overestimated. PLoS ONE 8(3), e59289. doi:10.1371/journal.pone. 0059289

Buchardt B, Seaman P, Stockmann G, Vous M, Wilken U, Düwel L, Aa K, Jenner M, Kristensen RM, Petersen GH, Thorbjørn L (1997) Submarine columns of ikaite tufa. Nature 390:129-130

Buffan-Dubau E, Carman KR (2000) Diel feeding behavior of meiofauna and their relationships with microalgal resources. Limnol Oceanogr 45(2):381-395

Burton SM, Rundle SD, Jones MB (2001) The relationship between trace metal contamination and stream meiofauna. Environ Poll 111:159 167

Bussau C (1992) New deep-sea Tardigrada (Arthrotardigrada, Halechiniscidae) from a manganese nodule area oft he eastern South Pacific. Zool Scripta 21:79-91

Bussau C (1993) Taxonomische und ökologische Untersuchungen an Nematoden des Peru-Beckens. Dissertation, Christian-AlbrechtsUniversität zu Kiel

Bussau C, Schriever G, Thiel H (1995) Evaluation of abyssal metazoan meiofauna from a manganese nodule area of the eastern South Pacific. Vie Milieu 46(1):39-48 
Carpentier A, Como S, Dupuy C, Lefrançois C, Feunteun E (2014) Feeding ecology of Liza spp. in a tidal flat: evidence of the importance of primary production (biofilm) and associated meiofauna. $\mathrm{J}$ Sea Res 92:86-91

Carman KR, Thistle D, Fleeger JW, Barry JP (2004) Influence of introduced $\mathrm{CO}_{2}$ on deep-sea metazoan meiofauna. J Oceanogr 60:767772

Carriço R, Zeppilli D, Quillien N, Grall J (2013) Can meiofauna be a good biological indicator of the impacts of eutrophication caused by green macroalgal blooms? Les cahiers naturalistes de l'Observatoire marin 2(1):9-16

Chung JS, Schriever G, Sharma R, Yamazaki T (2002) Deep Seabed Mining Environment: Preliminary Engineering and Environmental Assessment. Fourth ISOPE Ocean Mining Symposium. International Society of Offshore and Polar Engineers, pp 19

Collins M, An S-I, Cai W, Ganachaud A, Guilyardi E et al (2010) The impact of global warming on the tropical Pacific Ocean and El Nino. Nat Geosci 3(6):391-397

Coma R, Ribes M, Serrano E, Jiménez E, Salat J, Pascual J (2009) Global warming-enhanced stratification and mass mortality events in the Mediterranean. Proc Natl Acad Sci U S A 106:6176-6181

Cook AA, Lambshead PJD, Hawkins LE, Mitchell N, Levin LA (2000) Nematode abundance at the oxygen minimum zone in the Arabian Sea. Deep Sea Res Part I 47:75-85

Coull BC, Hicks GRF, Wells JBJ (1981) Nematode/Copepod ratios for monitoring pollution: a rebuttal. Mar Pollut Bull 12:378-381

Coull BC, Chandler GT (1992) Pollution and meiofauna: field, laboratory, and mesocosm studies. Oceanograph Mar Biol Ann Rev 30:191271

Covich AP, Austen MC, Bärlocher F, Chauvet E, Cardinale BJ, Biles CL, Inchausti P, Dangles O, Solan GMO, Statzner MB (2004) The role of biodiversity in the functioning of freshwater and marine benthic ecosystems. Bioscience 54(8):767-775

Curini-Galletti M, Artois T, Delogu V, De Smet WH, Fontaneto D et al (2012) Patterns of diversity in soft-bodied meiofauna: dispersal ability and body size matter. PLoS ONE 7(3), e33801. doi:10.1371/ journal.pone. 0033801

Dahl U, Breitholtz M (2008) Integrating individual ecdysteroid content and growth-related stressor endpoints to assess toxicity in a benthic harpacticoid copepod

Danovaro R (2010) Methods for the study of deep-sea sediments, their functioning and biodiversity. CRC Press, Boca Raton

Danovaro R, Dell'Anno A, Pusceddu A (2004a) Biodiversity response to climate change in a warm deep sea. Ecol Lett 7:821-828

Danovaro R, Gambi C, Luna GM, Mirto S (2004b) Sustainable impact of mussel farming in the Adriatic Sea (Mediterranean Sea): evidence from biochemical, microbial and meiofaunal indicators. Mar Pollut Bull 49(4):325-333

Danovaro R, Scopa M, Gambi C, Fraschetti S (2007) Trophic importance of subtidal metazoan meiofauna: evidence from in situ exclusion experiments on soft and rocky substrates. Mar Biol 152:339-350

Danovaro D, Gambi C, Dell'Anno A, Corinaldesi C, Fraschetti S et al (2008) Exponential decline of deep-sea ecosystem functioning linked to benthic biodiversity loss. Curr Biol 18:1-8

Dashfield SL, Somerfield PJ, Widdicombe S, Austen MC, Nimmo M (2008) Impacts of ocean acidification and burrowing urchins on within-sediment $\mathrm{pH}$ profiles and subtidal nematode communities. J Exp Mar Biol Ecol 365:46-52

De Mesel I, Derycke S, Swings J, Vincx M, Moens T (2006) Role of nematodes in decomposition processes: does within-trophic group diversity matter? Mar Ecol-Prog Ser 321:157-166

De Troch M, Roelofs M, Riedel B, Grego M (2013) Structural and functional responses of harpacticoid copepods to anoxia in the Northern Adriatic: an experimental approach. Biogeosciences 10:4259-4272
Decho AW (1990) Microbial esopolymer secretions in ocean environments: their role(s) in food webs Oceanogr. Mar Biol Ann Rev 28: $73-153$

Derycke S, Hendrick F, Backeljau T, D’Hondt S, Camphijn L, Vincx M, Moens T (2207) Effects of sublethal abiotic stressors on population growth and genetic diversity of Pellioditis marina (Nematoda) from the Westerschelde estuary. Aquat Toxicol 82:110-119

Diaz RL, Rosenberg R (1995) Marine benthic hypoxia: a review of its ecological effects and the behavioural responses of benthic macrofauna. Oceanogr Mar Biol Ann Rev 33:245-303

Doney SC, Ruckelshaus M, Duffy JE, Barry JP, Chan F et al (2012) Climate change impacts on marine ecosystems. Ann Rev Mar Sci 4:11-37

Doney SC, Fabry VJ, Feely RA, Kleypas JA (2009) Ocean acidification: the other CO2 problem. Ann Rev Mar Sci 1:169-192

Dos Santos GAP, Derycke S, Fonsêca-Genevois VG, Coelho LCBB, Correia MTS, Moens T (2008) Differential effects of food availability on population growth and fitness of three species of estuarine, bacterial-feeding nematodes. J Exp Mar Biol Ecol 355(1):27-40

Duarte CM, Cebrian J (1996) The fate of marine autotrophic production. Limnol Oceanogr 41:1758-1766

Durack P, Wijffels SE (2010) Fifty-year trends in global ocean salinities and their relationship to broad-scale warming. J Clim 23:4342-4362

Edwards M, Anthony J (2004) Richardson impact of climate change on marine pelagic phenology and trophic mismatch. Nature 430:881884

Edwards DP, Tobias JA, Sheil D, Meijaard E, Laurance WF (2014) Maintaining ecosystem function and services in logged tropical forests. Trends Ecol Evol 29:511-520

Ek H, Nilsson E, Birgersson G, Dave G (2007) TNT leakage through sediment to water and toxicity to Nitocra spinipes. Ecotox Environ Safe 67(3):341-348

Engler R, Saunders L, Wright T (1991) Environmental effects of aquatic disposal of dredged material. Env Prof 13:317-325

Ernst SR, Morvan J, Geslin E, Le Bihan A, Jorissen FJ (2006) Benthic foraminiferal response to experimentally induced Erika oil pollution. Mar Micropaleontol 61:76-93

Escaravage V, Garcia ME, Castel J (1989) The distribution of meiofauna and its contribution to detritic pathway in tidal flats (Arcachon Bay, France). In: Ros JD (ed) Topics in Marine Biology, Scientifica Marina, 53vol, pp 551-559

Fenchel (1978) The ecology of micro- and meiobenthos. Ann Rev Ecol Syst 9:99-121

Ferraro L, Sprovieri M, Alberico I, Lirer F, Prevedello L, Marsella E (2006) Benthic foraminifera and heavy metals distribution: a case study from the Naples harbour (Tyrrhenian Sea, Southern Italy). Environ Pollut 142:274-287

Fleeger JW, Johnson DS, Carman KR, Weisenhorn PB, Gabriele A, Thistle D, Barry JP (2010) The response of nematodes to deep-sea CO2 sequestration: a quantile regression approach. Deep-Sea Res Pt I 57:696-707

Fleeger JW, Carman K (2011) Experimental and genetic studies of meiofauna assess environmental quality and reveal mechanisms of pollution fate and effects. Vie et Milieu 61:1-26

Fonseca VG, Carvalho GR, Sung W, Johnson HF, Power DM et al (2010) Second-generation environmental sequencing unmasks marine metazoan biodiversity. Nature Comm 1:98

Forster SJ (1998) Osmotic stress tolerance and osmoregulation of intertidal and subtidal nematodes. J Exp Mar Biol Ecol 224:109-125

Fontanier C, Duros P, Toyofuku T, Oguri K, Koho KA (2014) Living (stained) deep-sea foraminifera off Hachinohe (NE Japan, Western Pacific): environmental interplay in oxygen-depleted ecosystems. Journal Foramin Res 44:281-299

Forchino A, Borja A, Brambilla F, Rodríguez JG, Muxika I, Terova G, Saroglia M (2011) Evaluating the influence of off-shore cage 
aquaculture on the benthic ecosystem in Alghero Bay (Sardinia, Italy) using AMBI and M-AMBI. Ecol Indic 11(5):1112-1122

Freedman B (2014) Global environmental change. Springer, Berlin

Frenzel P, Boomer I (2005) The use of ostracods from marginal marine, brackish waters as bioindicators of modern and Quaternary environmental change. Palaeogeo Palaeoclim Palaeoecol 225:68-92

Gallitelli M, Ungaro N, Addante LM, Procacci V, Silver NG, Sabbà C (2005) Respiratory illness as a reaction to tropical algal blooms occurring in a temperate climate. Jama 293(21):2595-2600

Galtsova VV, Kulangieva LV, Pogrebov VB (2004) Meiobenthos of the former nuclear test area and nuclear waste disposal grounds around the Novaya Zemlya Archipelago (Barents and Kara Seas). Russ J Mar Biol 30(4):231-240

Garcia R, Johnstone RW (2006) Efffects of Lyngbya majuscule (Cyanophycea) blooms on sediment nutrients and meiofaunal assemblages in seagrass beds in Moreton Bay, Australia. Mar Fresh Res 57(2):155-165

Gee JM, Somerfield PJ (1997) Do mangrove diversity and leaf litter decay promote meiofaunal diversity? J Exp Mar Biol Ecol 218: $13-33$

Gerlach SA (1971) On the importance of marine meiofauna for benthos communities. Oecologia 6(2):176-190

Gerlach SA (1978) Food-chain relationships in subtidal silty sand marine sediments and the role of meiofauna in stimulating bacterial productivity. Oecologia 33:55-69

Gerlach SA, Schrage M (1971) Life cycles in marine meiobenthos. Experiments at various temperatures with Monhystera disjuncta and Theristus pertenuis (Nematoda). Mar Biol 9:274-280

Giere O (1993) Meiobenthology: the microscopic fauna in aquatic sediments. Springer-Verlag, Berlin

Giere O (2009) Meiobenthology. The microscopic motile fauna of aquatic sediments, 2nd edn. Springer-Verlag, Berlin

Gingold R, Moens T, Rocha-Olivares A (2013) Assessing the response of nematode communities to climate change-driven warming: a microcosm experiment. PLoS ONE 8(6), e66653. doi:10.1371/journal. pone. 0066653

Glock N, Schönfeld J, Eisenhauer A, Hensen C, Mallon J, Sommer S (2012) The role of benthic foraminifera in the benthic nitrogen cycle of the Peruvian oxygen minimum zone. Biogeosci Discuss 9: $17775-17817$

Gollasch S, Lenz J, Dammer M, Andres HG (2000) Survival of tropical ballast water organisms during a cruise from the Indian Ocean to the North Sea. J Plankton Res 22(5):923-937

Gollasch S (2002) The importance of ship hull fouling as a vector of species introductions into the North Sea. Biofouling: The Journal of Bioadhesion and Biofilm Research 18:105-121

Gontikaki E, van Oevelen D, Soetaert K, Witte U (2011) Food web flows through a sub-arctic deep-sea benthic community. Prog Oceanog 91: 245-259

Gooday AJ (2003) Benthic Foraminifera (Protista) as tools in deepwater palaeoceanography: environmental influences on faunal characteristics. Adv Mar Biol 46:1-90

Gooday AJ, Bernhard JM, Levin LA, Suhr SB (2000) Foraminifera in the Arabian Sea oxygen minimum zone and other oxygen-deficient settings: taxonomic composition, diversity, and relation to metazoan faunas. Deep-Sea Res Pt II 47:25-54

Gooday AJ, Levin LA, Aranda da Silva A, Bett BJ, Cowie GL et al (2009a) Faunal responses to oxygen gradients on the Pakistan Margin: a comparison of foraminiferans, macrofauna and megafauna. Deep-Sea Res Pt II 56:488-502

Gooday AJ, Jorissen F, Levin LA, Middelburg JJ, Naqvi SWA et al (2009b) Historical records of coastal eutrophication-induced hypoxia. Biogeosciences 6:1707-1745

Gooday AJ, Bett BJ, Escobar E, Ingole B, Levin LA et al (2010) Biodiversity and habitat heterogeneity in oxygen minimum zones. Mar Ecol 31:125-147
Górska B, Grzelak K, Kotwicki L, Hasemann C, Schewe I et al (2014) Bathymetric variations in vertical distribution patterns of meiofauna in the surface sediments of the deep Arctic ocean (HAUSGARTEN, Fram strait). Deep Sea Res Part I 91:36-49

Green MA, Aller RC, Aller JY (1993) Carbonate dissolution and temporal abundances of foraminifera in long island sound sediments. Limnol Oceanogr 38:331-345

Grego M, De Troch M, Forte J, Malej A (2009) Main meiofauna taxa as an indicator for assessing the spatial and seasonal impact of fish farming. Mar Pollut Bull 58(8):1178-1186

Grego M, Stachowitsch M, Troch MD, Riedel B (2013) Cell Tracker Green labelling vs. Rose Bengal staining: CTG wins by points in distinguishing living from dead anoxia-impacted copepods and nematodes. Biogeosciences 10:4565-4575

Grzelak K, Kotwicki L (2014) Halomonhystera disjuncta- a youngcarrying nematode first observed for the Baltic Sea in deep basins within chemical munitions disposal sites. Deep Sea Res Part II. doi: 10.1016/j.dsr2.2014.12.007

Grzymski J, Schofield OM, Falkowski PG, Bernhard JM (2002) The function of plastids in the deep-sea foraminifer, Nonionella stella. Limnol Ocean 47:1569-1580

Guerrini A, Colangelo MA, Ceccherelli VU (1998) Recolonization patterns of meiobenthic communities in brackish vegetated and unvegetated habitats after induced hypoxia/anoxia. Hydrobiol 375(376):73-87

Guidi-Guilvard LD, Gasparini S, Lemée R (2012) The negative impact of Ostreopsis cf. ovata on phytal meiofauna from the coastal NW Mediterranean. Cryptogam Algol 33(2):121-128

Guinotte JM, Fabry VJ (2008) Ocean acidification and its potential effects on marine ecosystems. Year in Ecology and Conservation Biology 2008(1134):320-342

Gutt J, Barratt I, Domack E, d'Udekemd'Acoz C, Dimmler W et al (2011) Biodiversity change after climate-induced ice-shelf collapse in the Antarctic. Deep Sea Res Part II 58:74-83

Gwyther J (2003) Nematode assemblages from Avicennia marina leaf litter in a temperate mangrove forest in south-eastern Australia. Mar Biol 142:289-297

Gwyther D, Batterham GJ, Waworuntu J, Gultom TH, Prayogo W et al (2009) Recolonisation of mine tailing by meiofauna in mesocosm and microcosm experiments. Mar Poll Bull 164:841-850

Gyedu-Ababio TK, Furstenberg JP, Baird D, Vanreusel A (1999) Nematodes as indicators of pollution: a case study from the Swartkops River system, South Africa. Hydrobiol 397:155-169

Gyedu-Ababio TK, Baird D (2006) Response of meiofauna and nematode communities to increased levels of contaminants in a laboratory microcosm experiment. Ecotox Environ Safe 62:443-450

Hack LA, Tremblay LA, Wratten SD, Lister A, Keesing V (2007) Benthic meiofauna community composition at polluted and non-polluted sites in New Zealand intertidal environments. Mar Pollut Bull 54: $1801-1812$

Hale R, Calosi P, McNeill L, Mieszkowska N, Widdicombe S (2011) Predicted levels of future ocean acidifi cation and temperature rise could alter community structure and biodiversity in marine benthic communities. Oikos 120:661-674

Hallock P, Lidz BH, Cockey-Burkhard EM, Donnelly KB (2003) Foraminifera as bioindicators in coral reef assessment and monitoring: the FORAM index. In Coastal Monitoring through Partnerships. Springer, Netherlands, pp 221-238

Harvey R, Luoma SN (1985) Effect of adherent bacteria and bacterial extracellular polymers upon assimilation by Macoma balthica of sediment bound Cd, Zn and Ag. Mar Ecol Prog Ser 22:281-289

Hechtel GJ, Ernst EJ, Kalin RJ (1970) Biological effects of thermal pollution, Northport, New York. Marine Sciences Research Center, State University of New York, Technical Report Series 3. pp 116

Heip C, Duineveld G, Flach E, Graf G, Helder W et al (2001) The role of the benthic biota in sedimentary metabolism and sediment-water 
exchange processes in the Goban Spur area (NE Atlantic). Deep-Sea Res Pt II 48:3223-3243

Helly JJ, Levin LA (2004) Global distribution of naturally occurring marine hypoxia on continental margins. Deep-Sea Research Pt I 51:1159-1168

Hentschel BT, Jumars PA (1994) In Situ chemical inhibition of benthic diatom growth affects recruitment of competing, permanent and temporary meiofauna. Limnol Oceanogr 39(4):816-838

Hessler RR, Jumars PA (1974) Abyssal community analysis from replicate box cores in the central North Pacific. Deep-Sea Res 21:185209

Hinz H, Hiddink JG, Forde J, Kaiser MJ (2008) Large-scale responses of nematode communities to chronic otter-trawl disturbance. Can J Fish Aquat Sci 65:723-732

Hoegh-Guldberg O, Mumby PJ, Hooten AJ, Steneck RS, Greenfield P et al (2007) Coral reefs under rapid climate change and ocean acidification. Science 318(5857): 1737-1742

Hooper DU, Chapin FS, Ewel JJ, Hector A, Inchausti P et al (2005) Effects of biodiversity on ecosystem functioning: a consensus of current knowledge. Ecol Monogr 75(1):33-35

Hopper BE, Fell JW, Cefalu RC (1973) Effect of temperature on life cycles of nematodes associated with the mangrove (Rhizophora mangle) detrital system. Mar Biol 23:293-296

Howell R (1983) Heavy metals in marine nematodes: uptake, tissue distribution and loss of copper and zinc. Mar Pollut Bull 14:263-268

Huys R, Møbjerg N, Kristensen RM (1997) New tantulocarid Polynyapodella ambrosei gen et sp nov. (Basipodellidae) from the Northeast Water Polynya (Greenland) with emphasis on the phylogeny of its host genus Cervinia (Copepoda: Harpacticoida). Cah Biol Mar 38:181-199

IAEA (International Atomic Energy Agency) (1999) Inventory of radioactive waste disposals at sea. IAEA-TECDOC-1105, Vienna, p 127

Ingels J, Tchesunov AV, Vanreusel A (2011) Meiofauna in the Gollum channels and the whittard canyon, Celtic margin-How local environmental conditions shape nematode structure and function. PLoS ONE. doi:10.1371/journal.pone.0020094

Ingels J, Vanreusel A, Brandt A, Catarino AI, David B, De Ridder C, Dubois P, Gooday AJ, Martin P (2012) Possible effects of global environmental changes on Antarctic benthos: a synthesis across five major taxa. Ecol Evolut 2:453-485

Ingels J, Dashfield SL, Somerfield PJ, Widdicombe S, Austen MC (2014) Interactions between multiple large macrofauna species and nematode communities - Mechanisms for indirect impacts of trawling disturbance. J Exp Mar Biol Ecol 456:41-49

Ingole BS, Goltekar R, Gonsalves S, Ansari ZA (2005) Recovery of deep-sea meiofauna after artificial disturbance in the Central Indian Basin. Mar Georesour Geotec 23:253-266

Ingole BS, Anshari ZA, Rathod V, Rodrigues N (2000) Response of meiofauna to immediate benthic disturbance in the central Indian ocean basin. Mar Georesour Geotec 18:263-272

IPCC (2014) Climate change 2014: impacts, adaptation, and vulnerability. Cambridge University Press, Cambridge

IPCC (2007) Climate change 2007: the physical science basis. In: Solomon $\mathrm{S}$ et al (eds) Contribution of working group I to the fourth assessment report of the intergovernmental panel on climate change. Cambridge University Press, Cambridge

Irizuki T, Ito H, Sako M, Yoshioka K, Kawano S, Nomura R, Tanaka Y (2015) Anthropogenic impacts on meiobenthic Ostracoda (Crustacea) in the moderately polluted Kasado Bay, Seto Inland Sea, Japan, over the past 70 years. Mar Pollut Bull 91:149-159

Jackson JBC (2001) What was natural in the coastal oceans? Proc Natl Acad Sci U S A 98:5411-5418

Jennings S, Dinmore TA, Duplisea DE, Warr KJ, Lancaster JE (2001) Trawling disturbance can modify benthic production processes. J Anim Ecol 70:459-475
Jensen P (1987) Feeding ecology of free living aquatic nematodes. Mar Ecol Prog Ser 35:187-196

Jessup CM, Kassen R, Forde SE, Kerr B, Buckling A, Rainey PB, Bohannan BJM (2004) Big questions, small worlds: microbial model systems in ecology. Trends Ecol Evol 19:189-197

Jochum M, Schneider FD, Crowe TP, Brose U, O'Gorman EJ (2012) Climate-induced changes in bottom-up and top-down processes independently alter a marine ecosystem. Philos T Roy Soc B 367(1605):2962-2970

Jones DOB, Yool A, Wei CL, Henson SA, Ruhl HA, Watson RA, Gehlen M (2013) Global reductions in seafloor biomass in response to climate change. Glob Change Biol 20:1861-1872

Jorissen FJ, Fontanier C, Thomas E (2007) Paleoceanographical proxies based on deep-sea benthic foraminiferal assemblage characteristics. In: Hillaire-Marcel C, de Vernal A (eds) Proxies in late Cenozoic paleoceanography: Pt2. Biological traces and biomarkers, Elsevier, pp 263-326

Kaiser MJ, Clarke KR, Hinz H, Austen MCV, Somerfield PJ, Karakassis I (2006) Global analysis of response and recovery of benthic biota to fishing. Mar Ecol Prog Ser 311:1-14

Kang T, Min WG, Rho HS, Park HS, Kim D (2014) Differential responses of a benthic meiofaunal community to an artificial oil spill in the intertidal zone. J Mar Biol Assoc UK 94(2):219-231

Kennedy AD, Jacoby CA (1999) Biological indicators of marine environemtnal health: meiofauna - a neglected benthic component? Environ Monit Assess 54:47-68

Kingston PF (2002) Long-term environmental impact of oil spills. Spill Sci Technol B 7(1-2):53-61

Koho KA, Piña-Ochoa E (2012) Benthic foraminifera: inhabitants of lowoxygen environments. In: Altenbach AV, Bernhard JM, Seckbach J (eds) Anoxia. Evidence for eukaryotic survival and paleontological strategies. Springer, Dordrecht, pp 249-285

Kotwicki L, Grzelak K, Beldowski J. Benthic communities in the chemical munitions dumping sites of the Baltic deeps with special focus on nematodes. Submitted to Deep-Sea Res Pt II

Kramer M, Swadling KM, Meiners KM, Kiko R, Scheltz A, Nicolaus M, Werner I (2011) Antarctic sympagic meiofauna in winter: comparing diversity, abundance and biomass between perennially and seasonally ice-covered regions. Deep Sea Res Part II 58(9-10):10621074

Kuipers BR, de Wilde PAWJ, Creutzberg F (1981) Energy flow in a tidal flat ecosystem. Mar Ecol Prog Ser 5:215-221

Kurihara H, Ishimatsu A, Shirayama Y (2007) Effects of elevated seawater $\mathrm{CO} 2$ concentration on the meiofauna. J Mar Sci Technol 15:1722

Laakmann S, Gerdts G, Erler R, Knebelsberger T, Martinez Arbizu P et al (2013) Comparison of molecular species identification for North Sea calanoid copepods (Crustacea) using proteome fingerprints and DNA sequences. Mol Ecol Resour 13:862-876

Lambshead PJD (1984) The Nematode/Copepod ratio: some anomalous results from the firth of Clyde. Mar Pollut Bull 15:256-259

Lambshead PJD, Brown CJ, Ferrero TJ, Hawkin LE, Smith CR, Mitchell $\mathrm{NJ}$ (2003) Biodiversity of nematode assemblages from the region of Clarion-Clipperton Fracture Zone, an area of commercial mining interest. BioMed Central Ecology 3:1-12

Lampadariou N, Hatziyanni E, Tselepides A (2005) Meiofaunal community structure in Thermaikos Gulf: reponse to intense trawling pressure. Cont Shelf Res 25:2254-2569

Le Cadre V, Debenay J-P (2006) Morphological and cytological responses of Ammonia (foraminifera) to copper contamination: implications for the use of foraminifera as bioindicators of pollution. Environ Pollut 143:304-317

Lebreton B, Richard P, Parlier EP, Guillou G, Blanchard GF (2011) Trophic ecology of mullets during their spring migration in a European saltmarsh: a stable isotope study. Estuar Coast Shelf Sci 91:502-510 
Leduc D, Rowden AA, Pilditch CA, Maas EW, Probert PK (2013) Is there a link between deep-sea biodiversity and ecosystem function? Mar Ecol 34:334-344

Leduc D, Rowden AA, Torres LG, Nodder SD, Pallentin A (2015) Distribution of macro-infaunal communities in phosphorite nodule deposits on Chatham Rise, Southwest Pacific: implications for management of seabed mining. Deep Sea Res Part I 99:105-118

Lee JJ (1980) Nutrition and physiology of the foraminifera. In: Levandowsky M, Hutner S (eds) Biochemistry and physiology of protozoa, vol 3. Academic Press, New York, pp 43-66

Levin LA (2003) Oxygen minimum zone benthos: adaptation and community response to hypoxia. Oceanogr Mar Biol 41:1-45

Levin LA, Huggett CL, Wishner KF (1991) Control of deep-sea benthic community structure by oxygen and organic-matter gradients in the eastern Pacific Ocean. J Mar Res 49:763-800

Levings CD, Cordell JR, Ong S, Piercey GE (2004) The origin and identity of invertebrate organisms being transported to Canada's Pacific coast by ballast water. Can J Fish Aquat Sci 61(1):1-11

Liu WS, Cheung SG, Shin PKS (2009) Meiofauna with special reference to nematodes in trawling ground of subtropical Hong Kong. Mar Poll Bull 58:607-615

Liu WS, Xu WZ, Cheung SG, Shin PKS (2011) Response of meiofaunal community with special reference to nematodes upon deployment of artificial reefs and cessation of bottom trawling in subtropical waters, Hong Kong. Mar Poll Bull 63:376-384

Lizhe C, Sujing F, Jie Y, Xiping Z (2012) Distribution of meiofaunal abundance in relation to environmental factors in Beibu Gulf, South China Sea. Acta Oceanol Sin 31:92-103

Loreau M, Naeem S, Inchausti P, Bengtsson J, Grime JP, Hector A, Hooper DU, Huston MA, Raffaelli D, Schmid B, Tilman D, Wardle DA (2001) Biodiversity and ecosystem functioning: current knowledge and future challenges. Science 294:804

Louati H, Said OB, Soltani A, Cravo-Laureau C, Duran R, et al. (2014) Responses of a free-living benthic marine nematode community to bioremediation of a PAH mixture. Environ Sci Pollut R: 1-12

Mahaut ML, Sibuet M, Shirayama Y (1995) Weight-dependent respiration rates in deep-sea organisms. Deep-Sea Research I 42:15751582

Mahmoudi E, Essid N, Beyrem H, Hedfi A, Boufahja F, Vitiello P, Aissa P (2005) Effects of hydrocarbon contamination on a free living marine nematode community: results from microcosm experiments. Mar Pollut Bull 50:1197-1204

Mallon J, Glock N, Schönfeld J (2012) The response of benthic foraminifera to low-oxygen conditions of the Peruvian oxygen minimum zone. In: Altenbach AV, Bernhard JM, Seckbach J (eds) ANOXIA: evidence for eukaryote survival and paleontological strategies: cellular origin, life in extreme habitats and astrobiology 21, vol 21. Springer, Dordrecht, pp 305-321

Mascart T, Lepoint G, De Troch M (2013) Meiofauna and harpacticoid copepods in different habitats of a Mediterranean seagrass meadow. J Mar Biol Assoc UK 93:1557-1566

Mascart T, Lepoint G, Deschoemaeker S, Binard M, Remy F, De Troch M (2015) Seasonal variability of meiofauna, especially harpacticoid copepods, in Posidonia oceanica macrophytodetritus accumulations. J Sea Res 95:149-160

Matear RJ, Hirst AC (2003) Long-term changes in dissolved oxygen concentrations in the ocean caused by protracted global warming. Global Biogeochem Cy 17(4):1125

Mateo MA, Romero J (1997) Detritus dynamics in the seagrass Posidonia oceanica: elements for an ecosystem carbon and nutrient budget. Mar Ecol Prog Ser 151:43-53

Mazzola A, Favaloro E, Sarà G (1999) Comparative growth of Diplodus puntazzo (Cetti, 1777) in different condition of cultivations (Pisces: Sparidae) (Southern Tyrrhenian Sea). Aquacult Res 30:773-780

McIntyre-Wressnig A, Bernhard JM, McCorkle DC, Hallock P (2013) Non-lethal effects of ocean acidification on the symbiont-bearing benthic foraminifer Amphistegina gibbosa. Mar Ecol Prog Ser 472:45-60

Miljutin DM, Miljutina MA (2009a) Description of Bathynema nodinautensis gen. n., sp. n. and four new Trophomera species (Nematoda: Benthimermithidae) from the Clarion-Clipperton Fracture Zone (Eastern Tropic Pacific), supplemented with the keys to genera and species. In: Brökeland W, George KH (eds), Deep-Sea taxonomy-a contribution to our knowledge of biodiversity. Zootaxa 2096:173-196

Miljutin DM, Miljutina MA (2009b) Deep-sea nematode species of family Microlaimidae from the Clarion-Clipperton Fracture Zone (North-Eastern Tropic Pacific), with the descriptions of three new species. In: Brökeland W, George KH (eds), Deep-Sea taxonomya contribution to our knowledge of biodiversity. Zootaxa 2096:137172

Miljutin DM, Miljutina MA, Martınez Arbizu P, Galéron J (2011) Deepsea nematode assemblage has not recovered 26 years after experimental mining of polymetallic nodules (Clarion-Clipperton Fracture Zone, Tropical Eastern Pacific). Deep-Sea Res Pt I 58:885-897

Miljutina MA, Miljutin DM (2012) Seven new and four known species of the genus Acantholaimus (Nematoda: Chromadoridae) from the abyssal manganese nodule field (Clarion-Clipperton Fracture Zone, North-Eastern Tropical Pacific). Helgol Mar Res 66:413-462

Miljutina MA, Miljutin DM, Mahatma R, Galéron J (2010) Deep-sea nematode assemblages of the Clarion-Clipperton Nodule Province (Tropical North-Eastern Pacific). Mar Biodiv 40:1-15

Mirto S, Gristina M, Sinopoli M, Maricchiolo G, Genovese L, Vizzini S, Mazzola A (2012) Meiofauna as an indicator for assessing the impact of fish farming at an exposed marine site. Ecol Indic 18:468 476

Mirto S, Bianchelli S, Gambi C, Krzelj M, Pusceddu A et al (2010) Fishfarm impact on metazoan meiofauna in the Mediterranean Sea: analysis of regional vs. habitat effects. Mar Environ Res 69(1):38-47

Modig H, Olafsson E (1998) Responses of Baltic benthic invertebrates to hypoxic events. J Exp Mar Biol Ecol 229:133-148

Moens T, Vincx M (2000) Temperature and salinity constraints on the life cycle of two brackish-water nematode species. J Exp Mar Biol Ecol 243:115-135

Moens T, Braeckman U, Derycke S, Fonseca G, Gallucci F, et al. (2014) Ecology of free-living marine nematodes. In: Andreas SchmidtRhaesa (ed), Nematoda, 2ed, De Gruyter pp 109-152

Mojtahid M, Jorissen F, Pearson TH (2008) Comparison of benthic foraminiferal and macrofaunal responses to organic pollution in the Firth of Clyde (Scotland). Mar Pollut Bull 56:42-76

Montagna PA, Baguley JG, Cooksey C, Hartwell I, Hyde LJ et al (2013) Deep-sea benthic footprint of the deepwater horizon blowout. PLoS ONE 8, e70540

Mora C, Wei CL, Rollo A, Amaro T, Baco AR et al (2013) Biotic and human vulnerability to projected changes in ocean biogeochemistry over the 21st century. PLoS Biol 11(10), e1001682. doi:10.1371/ journal.pbio.1001682

Moreno M, Vezzulli L, Marin V, Laconi P, Albertelli C, Fabiano M(2008) The use of meiofauna diversity as an indicator of pollution in harbours ICES J Mar Sci 1428-35

Murray JW (2006) Ecology and applications of benthic foraminifera. Cambridge University Press, Cambridge, p 426

Murrell MC, Fleeger JW (1989) Meiofauna abundance on the Gulf of Mexico continental shelf affected by hypoxia. Cont Shelf Res 9: 1049-1062

Nascimento FJA, Karlson AML, Näslund J, Elmgren R (2011) Diversity of larger consumers enhances interference competition effects on smaller competitors. Oecologia 166:337-347

Nascimento FJA, Näslund J, Elmgren R (2012) Meiofauna enhances organic matter mineralization in soft sediment ecosystems. Limnol Oceanogr 57(1):338-346 
Neira C, Rackemann M (1996) Black spots produced by buried macroalgae in intertidal sandy sediments of the Wadden Sea: Effects on the meiobenthos. J Sea Res 36:153-170

Neira C, Sellanes J, Soto A, Gutiérrez D, Gallardo VA (2001) Meiofauna and sedimentary organic matter off Central Chile: response to changes caused by the 1997-1998 El Niño. Oceanol Acta 24:313328

Netto SA, Valgas I (2010) The response of nematode assemblages to intensive mussel farming in coastal sediments (Southern Brazil). Environ Monit Assess 162:81-93

Newell RIE (2004) Ecosystem influences of natural and cultivated populations of suspension-feeding bivalve molluscs: a review. J Shellfish Res 23(1):51-61

Nomaki H, Heinz P, Hemleben C, Kitazato H (2005a) Behavior and response of deep-sea benthic foraminifera to freshly supplied organic matter: a laboratory feeding experiment in microcosm environments. J Foramin Res 35:103-113

Nomaki H, Heinz P, Nakatsuka T, Shimanaga M, Kitazato H (2005b) Species-specific ingestion of organic carbon by deep-sea benthic foraminifera and meiobenthos: in situ tracer experiments. Limnol Oceanogr 50:134-146

Nomaki H, Heinz P, Nakatsuka T, Shimanaga M, Ohkouchi N et al (2006) Different ingestion patterns of 13C-labeled bacteria and algae by deep-sea benthic foraminifera. Mar Ecol Prog Ser 310:95-108

Nomaki H, Ohkouchi N, Heinz P, Suga H, Chikaraishi Y et al (2009) Degradation of algal lipids by deep-sea benthic foraminifera: an in situ tracer experiment. Deep-Sea Res Pt I 56:1488-1503

Nomaki H, Ogawa NO, Ohkouchi N, Toyofuku T, Kitazato H (2010) The role of meiofauna in deep-sea benthic food webs revealed by carbon and nitrogen stable isotope analyses. In: Ohkouchi N, Tayasu I, Koba K (eds) Earth, life, and isotopes. Kyoto University Press, Kyoto, pp 119-138

Nomaki H, Ogawa NO, Takano Y, Suga H, Ohkouchi N, Kitazato H (2011) Differing utilization of glucose and algal particulate organic matter by the deep-sea benthic organisms of Sagami Bay, Japan. Mar Ecol-Prog Ser 431:11-24

Ngo XQ, Smol N, Cah VA (2013) The meiofauna distribution in correlation with environmental characteristics in 5 Mekong estuaries, Vietnam. Cah Biol Mar 54:71-83

O'Gorman EJ, Pichler DE, Adams G et al (2012) Impacts of warming on the structure and functioning of aquatic communities: individual- to ecosystem-level responses. Adv Ecol Res 47:81-176

Olafsson E, Elmgren R (1997) Seasonal dynamics of sublittoral meiobenthos in relation to phytoplankton sedimentation in the Baltic Sea. Estuar Coast Shelf Sci 45:149-164

Oron S, Angel D, Goodman-Tchernov B, Merkado G, Kiflawi M, Abramovich S (2014) Benthic foraminiferal response to the removal of aquaculture fish cages in the Gulf of Aqaba-Eilat, Red Sea. Mar Micropaleontol 107:8-17

Pasotti F, Manini E, Giovanelli D, Wolfl AC, Monien D, et al. (2014) Antarctic shallow water benthos in an area of recent rapid glacier retreat. Mar Ecol 1-18

Parulekar AH, Harkantra SN, Ansari ZA, Matondkar SGP (1982) Abyssal benthos of the central Indian Ocean. Deep-Sea Res 29: $1531-1537$

Pawlowski J, Esling P, Lejzerowicz F, Cedhagen T, Wilding T (2014) Environmental monitoring through protist NGS metabarcoding: assessing the impact of fish farming on benthic foraminifera communities. Mol Ecol Resour. doi:10.1111/1755-0998.12261

Perez-Cruz LL, Machain-Castillo ML (1990) Benthic foraminifera of the oxygen minimum zone, continental shelf of the Gulf of Tehuantepec, Mexico. J Foramin Res 20:312-325

Pergent G, Romero J, Pergentmartini C, Mateo MA, Boudouresque CF (1994) Primary production, stocks and fluxes in the Mediterranean seagrass Posidonia oceanica. Mar Ecol Prog Ser 106:139-146
Phleger FB, Soutar A (1973) Production of benthic foraminifera in three east Pacific oxygen minima. Micropaleontology 19:110-115

Piña-Ochoa E, Høgslund S, Geslin E, Cedhagen T, Revsbech NP et al (2010a) Widspread occurrence of nitrate storage and denitification among Foraminifera and Gromiida. Proc Natl Acad Sci U S A 107: $1148-1153$

Piña-Ochoa E, Koho KA, Geslin E, Risgaard-Petersen N (2010b) Survival and life strategy of the foraminiferan Globobulimina turgida through nitrate storage and denitrification. Mar Ecol-Progr Ser 417:39-49

Pinto TK, Austen MC, Warwick RM, Somerfield PJ, Esteves AM et al (2013) Nematode diversity in different microhabitats in a mangrove region. Mar Ecol 34(3):257-268

Piot A, Nozais C, Archambault P (2014) Meiofauna affect the macrobenthic biodiversity-ecosystem functioning relationship. Oikos 123(2):203-213

Pogrebov VB, Fokin SI, Galtsova VV, Ivanov GI (1997) Benthic communities as influenced by nuclear testing and radioactive waste disposal off Novaya Zemlya in the Russian Arctic. Mar Poll Bull 35: 333

Pranovi F, Raicevich S, Franceschini G, Farrace MG, Giovanardi O (2000) Rapido trawling in the northern Adriatic Sea: effects on benthic communities in an experimental area. ICES J Mar Sci 57:517524

Pusceddu A, Fraschetti S, Mirto S, Holmer M, Danovaro R (2007) Effects of intensive mariculture on sediment biochemistry. Ecol Appl 17(5): $1366-1378$

Pusceddu A, Mea M, Canals M, Heussner S, Durrieu de Madron X et al (2013) Major consequences of an intense dense shelf water cascading event on deep-sea benthic trophic conditions and meiofaunal biodiversity. Biogeosciences 10:2659-2670

Pusceddu A, Bianchelli S, Martín J, Puig P, Palanques A, Masquéd P, Danovaro R (2014a) Chronic and intensive bottom trawling impairs deep-sea biodiversity and ecosystem functioning. Proc Natl Acad Sci U S A 111:8861-8866

Pusceddu A, Gambi C, Corinaldes C, Scopa M, Danovaro R (2014b) Relationships between Meiofaunal biodiversity and Prokaryotic Heterotrophic production in different tropical habitats and oceanic regions. PLoS ONE. doi:10.1371/journal.pone.0091056

Rabalais NN, Turner RE, Wiseman WJ (2002) Gulf of Mexico hypoxia, AKA" The dead zone. Ann Rev Ecol Syst 33:235-263

Rabalais NN, Diaz RJ, Levin LA, Turner RE, Gilbert D, Zhang J (2010) Dynamics and distribution of natural and human-caused hypoxia. Biogeosciences 7:585-619

Radwell AJ, Brown AV (2008) Benthic meiofauna assemblage structure of headwater streams: density and distribution of taxa relative to substrate size. Aquat Ecol 42(3):405-414

Radziejewska T (2002) Responses of deep-sea meiobenthic communities to sediment disturbance simulating effects of polymetallic nodule mining. Int Rev Hydrobiol 87(4):457-477

Radziejewska T (2014) Meiobenthos of the sub-equatorial North-Eastern Pacific Abyssal Seafloor: a synopsis. Meiobenthos in the subequatorial Pacific Abyss. Springer, Berlin, pp 29-65

Raes M, Rose A, Vanreusel A (2010) Response of nematode communities after large-scale ice-shelf collapse events in the Antarctic Larsen area. Glob Change Biol 16:1618-1631

Raffaelli DG, Mason CF (1981) Pollution monitoring with meiofauna, using the ratio of nematodes to copepods. Mar Pollut Bull 12:158 163

Renaud PE, Ambrose WG, Vanreusel A, Clough LM (2006) Nematode and macrofaunal diversity in central Arctic Ocean benthos. J Exp Mar Biol Ecol 330:297-306

Renaud-Mornant J, Gourbault N (1990) Evaluation of abyssal meiobenthos in the eastern central Pacific (Clarion-Clipperton Fracture Zone). Prog Oceanogr 24:317-329 
Revkov NK, Sergeeva NG (2004) Current state of zoobenthos at Crimean shores of the Black Sea. International Workshop on the Black Sea Benthos. Publ. Turkish Marine Res. Foundation, Turkey, pp 189217

Rex MA, Etter RJ, Morris JS, Crouse J, McClain CR et al (2006) Global bathymetric patterns of standing stock and body size in the deep-sea benthos. Mar Ecol-Prog Ser 317:1-8

Rex MA, Etter RJ (2010) Deep-Sea Biodiversity: Pattern and Scale. Harvard University Press, pp 354

Richmond CE, Wethey DS, Woodin SA (2007) Climate change and increased environmental variability: demographic responses in an estuarine harpacticoid copepod. Ecol Model 209:189-202

Ricketts ER, Kennett JP, Hill TM, Barry JP (2009) Effects of carbon dioxide sequestration on California margin deep-sea foraminiferal assemblages. Mar Micropaleontol 72:165-175

Riemann F, Schrage M (1978) The mucus-trap hypothesis on feeding of aquatic nematodes and implications for biodegradation and sediment texture. Oecologia 34:75-88

Riera P, Richard P, Grémare A, Blanchard G (1996) Food source of intertidal nematodes in the Bay of Marennes-Oléron (France), as determined by dual isotope analysis. Mar Ecol-Progr Ser 142:303309

Riera R, Monterroso O, Rodríguez M, Ramos E, Sacramento A (2011) Six-year study of meiofaunal dynamics in fish farms in Tenerife (Canary Islands, NE Atlantic Ocean). Aquat Ecol 45:221-229

Riera R, Sánchez-Jerez P, Rodríguez M, Monterroso Ó, Ramos E (2012) Long-term monitoring of fish farms: application of Nematode/ Copepod index to oligotrophic conditions. Mar Pollut Bull 64: 844-850

Risgaard-Petersen N, Langezaal A, Ingvardsen S, Schmid MC, Jetten MSM et al (2006) Evidence for complete denitrification in a benthic foraminifer. Nature 443:93-96

Rogers SI, Somerfield PJ, Schratzberger M, Warwick R, Maxwell TAD, Ellis JR (2008) Sampling strategies to evaluate the status of offshore soft sediment assemblages. Mar Pollut Bull 56:880-894

Rose A, Ingels J, Raes M, Vanreusel A, Martinez Arbizu P (2014) Longterm iceshelf-covered meiobenthic communities of the Antarctic continental shelf resemble those of the deep sea. Mar Biodiv. doi: 10.1007/s12526-014-0284-6

Rowe G, Lohse A, Hubbard F, Boland GS, Escobar Briones E, Deming J (2003) Preliminary trophodynamic carbon budget for the Sigsbee deep benthos, northern Gulf of Mexico. Am Fish Soc Symp 36, pp 225-238

Rudd MA (2014) Scientists' perspectives on global ocean research priorities. Front Mar Sci 1:36

Rudnick DT (1989) Time lags between the deposition and meiobenthic assimilation of phytodetritus. Mar Ecol Prog Ser 50:231-240

Ruiz F, Gonzalez-Regalado ML, Borrego J, Abad M, Pendon JG (2004) Ostracoda and foraminifera as short-term tracers of environmental changes in very polluted areas: the Odiel estuary (SW Spain). Environmen Pollut 129:49-61

Ruiz F, Abad M, Bodergat AM, Carbonel P, Rodriguez-Lazaro J, Yasuhara M (2005) Marine and brackish-water ostracods as sentinels of anthropogenic impacts. Earth-Sci Rev 72:89-111

Sandulli R, De Nicola GM (1989) Effects of organic enrichment on meiofauna: a laboratory study. Mar Pollut Bull 20:223-227

Scambos TA, Hulbe C, Fahnestock M (2003) Climate-induced ice shelf disintegration in the Antarctic Peninsula, in Antarctic Peninsula. In: Domack (ed) Climate variability: historical and Paleoenvironmental perspectives. Antarctic Research Series 79, AGU, Washington, pp 79-92

Schafer CT, Winters GV, Scott DB, Pocklington P, Cole FE, Honig C (1995) Survey of living foraminifera and polychaete populations at some Canadian aquaculture sites: potential for impact mapping and monitoring. J Foraminifer Res 25(3):243-259
Schmidt C, Heinz P, Kucera M, Uthicke S (2011) Temperature-induced stress leads to bleaching in larger benthic foraminifera hosting endosymbiotic diatoms. Limnol Oceanogr 56(3):1587-1602

Schönfeld J, Alve E, Geslin E, Jorissen F, Korsun S, Spezzaferri S (2012) The FOBIMO (FOraminiferal BIo-MOnitoring) initiativeTowards a standardised protocol for soft-bottom benthic foraminiferal monitoring studies. Mar Micropaleontol 94-95:1-13

Schratzberger M, Warwick RM (1998a) Effects of physical disturbance on nematode communities in sand and mud: a microcosm experiment. Mar Biol 130(4):643-650

Schratzberger M, Warwick RM (1998b) Effects of the intensity and frequency of organic enrichment on two estuarine nematode communities. Mar Ecol Progr Ser 164:83-94

Schratzberger M, Warwick RM (1999) Differential effects of various types of disturbances on the structure of nematode assemblages: an experimental approach. Mar Ecol Prog Ser 181:227-236

Schratzberger M, Gee JM, Rees HL, Boyd SE, Wall CM (2000) The structure and taxonomic composition of sublittoral meiofauna assemblages as an indicator of the status of marine environments. J Mar Biol Assoc UK 80(06):969-980

Schratzberger M, Dinmore TA, Jennings S (2002) Impacts of trawling on the diversity, biomass and structure of meiofauna assemblages. Mar Biol 140:83-93

Schratzberger M, Daniel F, Wall CM, Kilbride R, Macnaughton SJ, Boyd SE, Rees HL, Lee K, Swannell RPJ (2003) Response of estuarine meio- and macrofauna to in situ bioremediation of oil-contaminated sediment. Mar Pollut Bull 46:430-443

Sen Gupta BK, Machain-Castillo ML (1993) Benthic foraminifera in oxygen-poor habitats. Mar Micropal 20:183-201

Sergeeva NG, Zaika V (2013) The black sea meiobenthos in permanently hypoxic habitat. Acta Zool Bulg 65:139-150

Shapiro GI, Huthnance JM, Ivanov VV (2003) Dense water cascading off the continental shelf. J Geophys Res 108:3390

Sheills GM, Anderson KJ (1985) Pollution monitoring using the Nematode/Copepod ratio. Mar Pollut Bull 16:62-68

Sijp WP, von der Heydt AS, Dijkstra HA, Flögel S, Douglas P, Bijl PK (2014) The role of ocean gateways on cooling climate on long time scales. Glob Planet Chang 119:1-22

Singh R, Miljutin DM, Miljutina MA, Martinez Arbizu P, Ingole BS (2014) Deep-sea nematode assemblages from a commercially important polymetallic nodule area in the Central Indian Ocean Basin. Mar Biol Res 10(9):906-916

Smith CR, De Leo FC, Bernardino AF, Sweetman AK, Martinez Arbiz P (2008) Abyssal food limitation, ecosystem structure and climate change. Trends in Ecology and Evolution 23:518-528

Snider LJ, Burnett BR, Hessler RR (1984) The composition and distribution of meiofauna and nanofauna in a central North deep-sea area. Deep Sea Res Pt A31:1225-1249

Somerfield PJ, Gee JM, Warwick RM (1994) Soft sediment meiofaunal community structure in relation to a long-term heavy metal gradient in the Fal estuary system. Mar Ecol Prog Ser 105:79-88

Somot S, Sevault F, Deque M (2006) Transient climate change scenario simulation of the Mediterranean Sea for the twenty-first century using a high-resolution ocean circulation model. Clim Dynam 27: 851-879

Sørensen MV, Kristensen RM (2000) Marine Rotifera from Ikka Fjord, SW Greenland: with a description of a new species from the rare mineral ikaite. Meddelelser Om Groenland, Bioscience 51:1-46

Stramma L, Prince ED, Schmidtko S, Luo J, Hoolihan JP, Visbeck M, Wallace DWR, Brandt P, Körtzinger A (2012) Expansion of oxygen minimum zones may reduce available habitat for tropical pelagic fishes. Nat Clim Chang 2:33-37

Stramma L, Johnson GC, Sprintall J, Mohrholz V (2008) Expanding oxygen-minimum zones in the tropical oceans. Science 320(5876): $655-658$ 
Sun X, Zhou H, Hua E, Xu S, Cong B et al (2015) Meiofauna and its sedimentary environment as an integrated indication of anthropogenic disturbance to sandy beach ecosystems. Mar Pollut Bull 88: 260-267

Sutherland TF, Levings CD, Petersen SA, Poon P, Piercey B (2007) The use of meiofauna as an indicator of benthic organic enrichment associated with salmonid aquaculture. Mar Pollut Bull 54:12491261

Talge HK, Hallock P (2003) Ultrastructural responses in field-bleached and experimentally stressed Amphistegina gibbosa (Class Foraminifera). J Eukaryot Microbiol 50:324-333

Teuber L, Schukat A, Hagen W, Auel H (2013) Distribution and ecophysiology of Calanoid Copepods in Minimum Zone in the Eastern Tropical Atlantic. PLoS One 8, e77590

Thiel H (2003) Anthropogenic impacts on the deep sea. In: Tyler PA (ed) Ecosystems of the Deep Oceans. Elsevier, Amsterdam, pp 427-472

Thiel H, Schriever G, Bussau C, Borowski C (1993) Manganese nodule crevice fauna. Deep-sea Rese Pt I 40(2):419-423

Thistle D (2001) Harpacticoid copepods are successful in the soft-bottom deep sea. Hydrobiologia 453(454):255-259

Thistle D, Carman KR, Sedlacek L, Brewer PG, Fleeger JW et al (2005) Deep-ocean, sediment-dwelling animals are sensitive to sequestered carbon dioxide. Mar Ecol Prog Ser 289:1-4

Thistle D, Sedlacek L, Carman KR, Fleeger JW, Brewer PG, Barry JP (2006) Simulated sequestration of industrial carbon dioxide at a deep-sea site: effects on species of harpacticoid copepods. J Exp Mar Biol Ecol 330:151-158

Thistle D, Sedlacek L, Carman KR, Fleeger JW, Brewer PG et al (2007) Exposure to carbon dioxide-rich seawater is stressful for some deepsea species: an in situ, behavioral study. Mar Ecol Prog Ser 340:916

Thurber AR, Sweetman AK, Narayanaswamy BE, Jones DOB, Ingels J, Hansman RL (2014) Ecosystem function and services provided by the deep sea. Biogeosciences 11(14):3941-3963

Tita G, Desrosiers G, Vincx M, Nozais C (2000) Predation and sediment disturbance effects of the intertidal polychaete Nereis virens (Sars) on associated meiofaunal assemblages. J Exp Mar Biol Ecol 243(2): 261-282

Tomimatsu H, Sasaki T, Kurokawa H, Bridle JR, Fontaine C et al (2013) Sustaining ecosystem functions in a changing world: a call for an integrated approach. J Appl Ecol 50:1124-1130

Torres-Pratts H, Schizas NV (2007) Meiofaunal colonization of decaying leaves of the red mangrove Rhizophora mangle, in Southwestern Puerto Rico. Caribb J Sci 43:127-137

Turner J, Bindschadler R, Convey P, di Prisco G, Fahrbach E, Gutt J, Hodgson D, Mayewski P, Summerhayes C (2009) Antarctic climate change and the environment - A contribution to the international polar year 2007-2008. SCAR, Cambridge

Van Colen C, Montserrat F, Verbist K, Vincx M, Steyaert M, Vanaverbeke $\mathrm{J}$ et al (2009) Tidal flat nematode responses to hypoxia and subsequent macrofauna-mediated alterations of sediment properties. Mar Ecol-Progr Ser 381:189-197

Van De Schootbrugge B, Gollner S (2013) Altered primary production during mass-extinction events. In: Bush AM, Pruss SB, Payne JL (eds) Ecosystem Paleobiology and Geobiology, The Paleontological Society Short Course, October 26, 2013. The Paleontological Society Papers

van Denderen PD, van Kooten T, Rijnsdorp AD (2013) When does fishing lead to more fish? Community consequences of bottom trawl fisheries in demersal food webs. Proc R Soc B 280

van der Wurff AWG, Kools SAE, Boivin MEY, Van den Brink PJ, van Megen HHM et al (2007) Type of disturbance and ecological history determine structural stability. Ecol Appl 17(1):190-202

Van Hoey G, Delahaut V, Derweduwen J, Devriese L, Dewitte B, Hostens K, Robbens J (2011) Biological and chemical effects of the disposal of dredged material in the Belgian Part of the North Sea (licensing period 2010-2011). ILVO-mededeling 109

Vanaverbeke J, Vincx M (2008) Short-term changes in nematode communities 1 from an abandoned intense sand extraction site on the Kwintebank (Belgian Continental Shelf) two years post cessation. Mar Environ Res 66(2):240-248

Vinagre C, Salgado JP, Mendonça V, Cabral H, Costa MJ (2012) Isotopes reveal fluctuation in trophic levels of estuarine organisms, in space and time. J Sea Res 72:49-54

Vassallo P, Fabiano M, Vezzulli L, Sandulli R, Marques JC, Jørgensen SE (2006) Assessing the health of coastal marine ecosystems: a holistic approach based on sediment micro and meio-benthic measures. Ecol Indic 6:525-542

Veillette J, Sarrazin J, Gooday AJ, Galéron J, Caprais J-C et al (2007a) Ferromanganese nodule fauna in the Tropical North Pacific Ocean: species richness, faunal cover and spatial distribution. Deep-Sea Res Pt I 54(11):1912-1935

Veillette J, Juniper SK, Gooday AJ, Sarrazin J (2007b) Influence of surface texture and microhabitat heterogeneity in structuring nodule faunal communities. Deep-Sea Res Pt I 54(11):1936-1943

Veit-Köhler G, Gerdes D, Quiroga E, Hebbeln D, Sellanes J (2009) Metazoan meiofauna within the oxygen-minimum zone off Chile: results of the 2001-PUCK expedition. Deep-Sea Res Pt II 56:11051111

Vidović J, Cosović V, Juracić M, Petricioli D (2009) Impact of fish farming on foraminiferal community, Drvenik Veliki Island, Adriatic Sea, Croatia. Mar Pollut Bull 58:1297-1309

Villano N, Warwick R (1995) Meiobenthic communities associated with seasonal cycle growth of Ulva rigida Agardh in the Palude della Rosa, Lagoon of Venice. Estuar Coast Shelf Sci 41:181-194

Vopel K, Dehmlow J, Johansson M, Arlt G (1998) Effects of anoxia and sulphide on populations of Cletocamptus confluens (Copepoda, Harpacticoida). Mar Ecol Prog Ser 175:121-128

Vopel K, Thiel H (2001) Abyssal nematode assemblages in physically disturbed and adjacent sites of the eastern equatorial Pacific. DeepSea Res II 48:3795-3808

Vranken G, Heip C (1986) Toxicity of copper, mercury and lead to a marine nematode. Mar Pollut Bull 17(10):453-457

Vranken G, Vanderhaeghen R, Heip C (1991) Effects of pollutants on life-history parameters of the marine nematode Monhystera disjuncta. ICES J Mar Sci 48:325-334

Wang S, Bailey D, Lindsay K, Moore K, Holland M (2014) Impacts of sea ice on the marine iron cycle and phytoplankton productivity. Biogeosci Discuss 11(2):2383-2418

Warwick RM (1981a) The Nematode/Copepod ratio and its use in pollution ecology. Mar Pollut Bull 12:329-333

Warwick RM (1981b) The influence of temperature and salinity on energy partitioning in the marine nematode Diplolaimelloides bruciei. Oecologia 51:318-325

Warwick RM (1987) Meiofauna: their role in marine detrital systems. In: Moriarty DJW, Pullin RSV (eds) Detritus and microbial ecology in aquaculture. ICLARM, Manila, pp 282-295

Warwick RM, Joint IR, Radford PJ (1979) Secondary production of the benthos in an estuarine environment. In: Jefferies RL, Davy AJ (eds) Ecological processes in coastal environments. Blackwell, Oxford, pp 429-450

Warwick RM, Platt HM, Clarke KR, Agard J, Gobin G (1990) Analysis of macrobenthic and meiobenthic community structure in relation to pollution and disturbance in Hamilton Harbour, Bermuda. J Exp Mar Biol Ecol 138:119-142

Warwick RM, Robinson J (2000) Sibling species in the marine pollution indicator genus Pontonema Leidy (Nematoda: Oncholaimidae), with a description of P. mediterranea sp. nov. J Nat Hist 34(5): 641-662

Watling L, Norse E (1998) Disturbance of the seabed by mobile fishing gear: a comparison to forest clearcutting. Conserv Biol 1180-1197 
Wernberg T, Russell BD, Moore PJ, Ling SD, Smale DA et al (2011) Impacts of climate change in a global hotspot for temperate marine biodiversity and ocean warming. J Exp Mar Biol Ecol 400:7-16

W sławski JM, Kendall MA, Wlodarska-Kowalczuk M, Iken K, K dra M et al (2011) Climate change effects on Arctic fjord and coastal macrobenthic diversity - observations and predictions. Mar Biodiv 41:71-85

Wetzel MA, Weber A, Giere O (2002) Re-colonization of anoxic/sulfidic sediments by marine nematodes after experimental removal of macroalgal cover. Mar Biol 141:679-689

Wetzel MA, Fleeger JW, Powers SP (2001) Effects of hypoxia and anoxia on meiofauna: a review with new data from the Gulf of Mexico. Coastal Estuar Stud 58:165-184

Widdicombe S, Dashfield SL, McNeill CL, Needham HR, Beesley A et al (2009) Effects of CO2 induced seawater acidification on infaunal diversity and sediment nutrient fluxes. Mar Ecol Prog Ser 379:59 75

Wigham BD, Hudson IR, Billet DSM, Wolff GH (2003) Is long-term change in the abyssal Northeast Atlantic driven by qualitative change in export flux? Evidence from selective feeding in deepsea holothurians. Prog Oceanogr 59:409-441

Woodward G (2010) Integrative ecology: from molecules to ecosystems. Volume 43 advances in ecological research. Academic Press, London

Woombs M, Laybournparry J (1984a) Feeding biology of Diplogasteritus nudicapitatus and Rhabsitis curvicaudata (Nematoda) related to food concentration and temperature in sewage treatment plants. Oecologia 64(2):163-167

Woombs M, Laybournparry J (1984b) Growth, reproduction and longevity in nematodes from sewage treatment plants. Oecologia 64(2): $168-172$
Worsaae K, Kristensen RM (2003) A new species of Paranerilla (Polychaeta: Nerillidae) from Northeast Greenland Waters, Arctic Ocean. Cah Biol Mar 44:23-39

Woulds C, Cowie GL, Levin LA, Andersson JH, Middelburg JJ et al (2007) Oxygen as a control on seafloor biological communities and their roles in sedimentary carbon cycling. Limnol Oceanogr 52:1698-1709

Würzberg L, Peters J, Brandt A (2011) Fatty acid patterns of Southern Ocean shelf and deep sea peracarid crustaceans and a possible food source, foraminiferans. Deep Sea Res Part II 58:19-20

Yamanaka T, Raffaelli D, White PCL (2010) Physical determinants of intertidal communities on dissipative beaches: implications of sealevel rise. Estuar Coast Shelf Sci 88:267-278

Yasuhara M, Hunt G, Cronin TM, Hokanishi N, Hodaka K et al (2012a) Climatic forcing of Quaternary deep-sea benthic communities in the North Pacific Ocean. Paleobiol 38(1):162-179

Yasuhara M, Hunt G, Breitburg D, Tsujimoto A, Katsuki K (2012b) Human-induced marine ecological degradation: micropaleontological perspectives. Ecol Evol 2(12):3242-3268

Yasuhara M, Okahashi H, Cronin TM, Rasmussen TL, Hunt G (2014) Response of deep-sea biodiversity to abrupt deglacial and Holocene climate changes in the North Atlantic Ocean. Global Ecol Biogeogr 23:957-967

Zeppilli D, Bongiorni L, Cattaneo A, Danovaro R, Serrão Santos R (2013) Meiofauna assemblages of the Condor Seamount (NorthEast Atlantic Ocean) and adjacent deep-sea sediments. Deep Sea Res Part II 98:87-100

Zeppilli D, Bongiorni L, Serrão Santos R, Vanreusel A (2014) Changes in nematode communities in different physiographic sites of the condor seamount (North-East Atlantic Ocean) and adjacent sediments. PLoS ONE 9(12), e115601 